\title{
Biomass burning fuel consumption rates: a field measurement database
}

T. T. van Leeuwen ${ }^{1,3}$, G. R. van der Werf ${ }^{1}$, A. A. Hoffmann ${ }^{2}$, R. G. Detmers ${ }^{1,3}$, G. Rücker $^{4}$, N. H. F. French ${ }^{5}$, S. Archibald ${ }^{6,7}$, J. A. Carvalho Jr. ${ }^{8}$, G. D. Cook ${ }^{9}$, W. J. de Groot ${ }^{10}$, C. Hély ${ }^{11}$, E. S. Kasischke ${ }^{12}$, S. Kloster ${ }^{13}$, J. L. McCarty ${ }^{5}$, M. L. Pettinari ${ }^{14}$, P. Savadogo ${ }^{15}$, E. C. Alvarado ${ }^{16}$, L. Boschetti ${ }^{17}$, S. Manuri ${ }^{18}$, C. P. Meyer ${ }^{19}$, F. Siegert ${ }^{20}$, L. A. Trollope ${ }^{21}$, and W. S. W. Trollope ${ }^{21}$

${ }^{1}$ Faculty of Earth and Life Sciences, VU University Amsterdam, Amsterdam, the Netherlands

${ }^{2}$ Independent Expert for Integrated Fire and Natural Resource Management, Sinsheim, Germany

${ }^{3}$ SRON Netherlands Institute for Space Research, Utrecht, the Netherlands

${ }^{4}$ ZEBRIS GbR, Munich, Germany

${ }^{5}$ Michigan Tech Research Institute, Michigan Technological University, Ann Arbor, Michigan, USA

${ }^{6}$ Natural Resources and the Environment, Council for Scientific and Industrial Research, Pretoria 0001, South Africa

${ }^{7}$ School of Animal, Plant and Environmental Sciences, University of the Witwatersrand, Johannesburg 2050, South Africa

${ }^{8}$ Faculty of Engineering, São Paulo State University, Campus of Guaratinguetá, Guaratinguetá, Brazil

${ }^{9}$ CSIRO Land and Water, Darwin, Northern Territory, Australia

${ }^{10}$ Natural Resources Canada-Canadian Forest Service, Sault Ste. Marie, Canada

${ }^{11}$ Centre de Bio-Archéologie et d'Écologie (CBAE UMR 5059 CNRS/Université Montpellier 2/EPHE),

Paléoenvironnements et Chronoécologie, Institut de Botanique, 163 rue Auguste Broussonnet, 34090 Montpellier, France

${ }^{12}$ Department of Geographical Sciences, University of Maryland, College Park, Maryland 20742, USA

${ }^{13}$ Land in the Earth System, Max Planck Institute for Meteorology, Hamburg, Germany

${ }^{14}$ Environmental Remote Sensing Research Group, Department of Geology, Geography and Environment,

Universidad de Alcalá, Alcalá de Henares, Spain

${ }^{15}$ World Agroforestry Centre (ICRAF) c/o International Crop Research Institute for the Semi-Arid Tropics (ICRISAT), West \& Central Africa Region BP 12404, Niamey, Niger

${ }^{16}$ School of Environmental and Forest Sciences, University of Washington, Seattle, Washington 98195, USA

${ }^{17}$ College of Natural Resources, University of Idaho, Moscow, Idaho 83844, USA

${ }^{18}$ Fenner School of Environment and Society, the Australian National University, Canberra, Australia

${ }^{19}$ CSIRO Marine and Atmospheric Research, Aspendale, Victoria, Australia

${ }^{20}$ Biology Department II, GeoBio Center, Ludwig Maximilian University, Großhadener Str. 2,

82152 Planegg-Martinsried, Germany

${ }^{21}$ Research \& Development, Working On Fire International, Nelspruit, South Africa

Correspondence to: T. T. van Leeuwen (t.t.van.leeuwen@sron.nl)

Received: 2 May 2014 - Published in Biogeosciences Discuss.: 5 June 2014

Revised: 14 October 2014 - Accepted: 3 November 2014 - Published: 19 December 2014 
Abstract. Landscape fires show large variability in the amount of biomass or fuel consumed per unit area burned. Fuel consumption (FC) depends on the biomass available to burn and the fraction of the biomass that is actually combusted, and can be combined with estimates of area burned to assess emissions. While burned area can be detected from space and estimates are becoming more reliable due to improved algorithms and sensors, FC is usually modeled or taken selectively from the literature. We compiled the peerreviewed literature on FC for various biomes and fuel categories to understand FC and its variability better, and to provide a database that can be used to constrain biogeochemical models with fire modules. We compiled in total 77 studies covering 11 biomes including savanna (15 studies, average FC of $4.6 \mathrm{t} \mathrm{DM}$ (dry matter) ha ${ }^{-1}$ with a standard deviation of 2.2), tropical forest $(n=19, \mathrm{FC}=126 \pm 77)$, temperate forest $(n=12, \mathrm{FC}=58 \pm 72)$, boreal forest $(n=16$, $\mathrm{FC}=35 \pm 24)$, pasture $(n=4, \mathrm{FC}=28 \pm 9.3)$, shifting cultivation $(n=2, \mathrm{FC}=23$, with a range of 4.0-43), crop residue $(n=4, \mathrm{FC}=6.5 \pm 9.0)$, chaparral $(n=3, \mathrm{FC}=27 \pm 19)$, tropical peatland $(n=4, \mathrm{FC}=314 \pm 196)$, boreal peatland $(n=2, \mathrm{FC}=42$ [42-43]), and tundra $(n=1, \mathrm{FC}=40)$. Within biomes the regional variability in the number of measurements was sometimes large, with e.g. only three measurement locations in boreal Russia and 35 sites in North America. Substantial regional differences in FC were found within the defined biomes: for example, $\mathrm{FC}$ of temperate pine forests in the USA was $37 \%$ lower than Australian forests dominated by eucalypt trees. Besides showing the differences between biomes, FC estimates were also grouped into different fuel classes. Our results highlight the large variability in FC, not only between biomes but also within biomes and fuel classes. This implies that substantial uncertainties are associated with using biome-averaged values to represent FC for whole biomes. Comparing the compiled FC values with co-located Global Fire Emissions Database version 3 (GFED3) FC indicates that modeling studies that aim to represent variability in $\mathrm{FC}$ also within biomes, still require improvements as they have difficulty in representing the dynamics governing FC.

\section{Introduction}

Landscape fires occur worldwide in all biomes except deserts, with frequencies depending mostly on type of vegetation, climate, and human activities (Crutzen, 1990; Cooke and Wilson, 1996; Andreae and Merlet, 2001; Bowman et al., 2009). The amount of fire-related research is increasing, partly due to improved abilities to monitor fires around the world using satellite data and appreciation of the important role of fires in the climate system and in air quality (Bowman et al., 2009, Johnston et al., 2012). Studies focusing on the effects of fires on the atmosphere require accurate trace gas and particle emissions estimates. Historically, these are based on the Seiler and Crutzen (1980) equation, multiplying burned area, fuel loads (abbreviated as "FL" in the remainder of the paper), combustion completeness (abbreviated as "CC" in the remainder of the paper), and emission factors over time and space of interest.

These four properties are obtained in different ways and, generally, uncertainties are substantial (van der Werf et al., 2010). The burned area may be estimated directly from satellite observations, with the MODerate resolution Imaging Spectroradiometer (MODIS) $500 \mathrm{~m}$ maps (Roy et al., 2005; Giglio et al., 2009) being currently the most commonly used products for large-scale assessments. Although small fires and fires obscured by forest canopies escape detection with this method (Randerson et al., 2012), the extent of most larger fires can be relatively well constrained in this way.

With burned area estimates improving, the other parameters may become the most uncertain component when estimating emissions (French et al., 2004) as they are less easily observed from space. In general, the FL is equivalent to the total biomass available. New studies do provide estimates of standing biomass (e.g., Baccini et al., 2012). However, fires do not necessarily affect standing biomass. Especially in savannas the trees are usually protected from burning by a thick barch, and in some of the literature the FL therefore has a more restrictive definition, referring to only that portion of the total available biomass that normally burns under specified fire conditions, which is often only the fine surface fuels. In both definitions, the FL is typically expressed as the mass of fuel per unit area on a dry weight basis. CC corresponds to the fraction of fuel exposed to a fire that was actually consumed or volatilized. Just like total FL, CC cannot be directly derived from satellite observations. Instead, these quantities are usually based on look-up tables of biome-averaged values, or are calculated from global vegetation models including dynamic global vegetation models (DGVM, e.g., Kloster et al., 2010) and biogeochemical models (e.g., Hély et al., 2007; van der Werf et al., 2010).

Another approach that has been developed over the past decade is the measurement of fire radiative power (FRP) (Wooster et al., 2003, 2005; Kaiser et al., 2012). FRP per unit area relates directly to the fuel consumption (abbreviated as " $\mathrm{FC}$ " in the remainder of the paper) rate, which again is proportional to the fire emissions. The FRP method has several advantages compared to the Seiler and Crutzen (1980) approach, such as the ability to detect smaller fires and the fact that the fire emissions estimates derived this way do not rely on FL or CC. One disadvantage is that the presence of clouds and smoke can prevent the detection of a fire, and the poor temporal resolution of polar orbiting satellites hampers the detection of fast-moving or short-lived fires (which still can show a burn scar in the burned area method), and makes the conversion of FRP to fire radiative energy (FRE, timeintegrated FRP) difficult. 
Finally, emission factors, relating the consumption of dry matter to trace gas and aerosol emissions of interest, are obtained by averaging field measurements for the different biomes. Andreae and Merlet (2001) have compiled these measurements into a database that is updated annually, while Akagi et al. (2011) used a similar approach to derive biomeaveraged emission factors but focused on measurement of fresh plumes only and provided more biome-specific information. The accompanying database is updated frequently and is online.

To improve and validate fire emissions models, it is crucial to gain a better overview of available FC measurements, as well as of the FL and CC components that together govern FC. This is obviously the case for emissions estimates based on burned area, but FRP estimates could also benefit from this information because one way to constrain these estimates is by dividing the fire-integrated FRE by the fire-integrated burned area, which in principle should equal FC.

Over the last few decades, many field measurements of FL and CC have been made over a range of biomes and geographical locations. An examination of these studies revealed several generalities: forested ecosystems in general show relatively little variability in FL over time for a given location, but CC can vary due to weather conditions. Fine fuels usually burn more completely than coarser fuels, and therefore CC in grassland savannas is often higher than in forested ecosystems. While CC in the savanna biome shows relatively little variability over time, the FL can vary on monthly timescales depending on season, time since fire, and grazing rates. Another generalization that can be made is that FL in boreal and tropical forests are relatively similar, but the distribution into components (organic soil, boles, peat) is very different, with FL in tropical forests being mostly composed of aboveground biomass, while in the boreal region the organic soil (including fermentation and humus layers) represents a large part of the FL. Overall CC is often higher in tropical forests though, leading to higher FC values.

While these findings are relatively easy to extract from the body of literature, what is lacking is a universal database listing all the available measurements so that they can be compared in a systematic way, used to constrain models, and to identify gaps in our knowledge with regard to spatial representativeness. Building on Akagi et al. (2011), who listed 47 measurements for nine fuel types, this paper is a first attempt to establish a complete database listing all the available FC field measurements for the different biomes that were found in the peer-reviewed literature. We focus on FC estimates, but if FL and/or CC were reported separately, these were included as well. The database, available at http://www.falw. $\mathrm{vu} / \sim$ gwerf/FC, will be updated when new information becomes available. In follow-up papers we aim to provide more in-depth analyses of the variability we found; the goal of this paper is to give a quantitative overview of FC measurements made around the world to improve large-scale fire emissions assessments. This paper is organized as follows: in Sect. 2, we list all the measurements and divide them into 11 different biomes. In that section we also provide a short summary of the methods used during the field campaigns, give a brief introduction to fire processes in each biome, and present data for different fuel classes (ground, surface, and crown fuels). Our findings are discussed in Sect. 3, and in addition a comparison between the FC field measurements and (1) the values used in the GFED3 (van der Werf et al., 2010) modeling framework, and (2) several FRE-derived estimates, is given. Finally, our results are summarized in Sect. 4.

\section{Measurements}

Figure 1 provides an overview of the locations where peerreviewed FC was measured in the field, overlaid on mean annual fire carbon (C) emissions (van der Werf et al., 2010). Field measurements of FC were conducted in most fire-prone regions in the world, including the "arc of deforestation" in Amazonia, the boreal regions of North America, and savannas and woodlands in Africa, South America and Australia. Due to ecological, technical, and logistical reasons (e.g., wildfire versus prescribed fire), the FL and FC sampling procedures at these measurement locations have ranged in scope from simple and rapid visual assessment (e.g., Maxwell, 1976; Sandberg et al., 2001) to highly detailed measurements of complex fuel beds along lines (line transect method: van Wagner, 1968) or in fixed areas (planar intersect method; Brown, 1971) that take considerable time and effort. Most of the studies we found in the literature rely on the planar intersect method (PIM), where fuel measurement plots are typically divided into multiple, randomized smaller subplots. The (small-size) biomass in these subplots is oven dried and weighed both pre- and post-fire to estimate the $\mathrm{CC}$ and to determine the FC. The consumption of larger-size material (diameter $>10 \mathrm{~cm}$ ) is often estimated based on experimental observations of randomly selected trunks and branches that were identified before the fire (Araújo et al., 1999). The PIM is mainly applied in prescribed burns, and obtaining FC measurements for large wildfires is logistically more challenging but can be based on comparing burned and adjacent unburned patches. Usually, the total FC of a fire is presented, but some studies also include separate values for different fuel categories of the total below-ground biomass (peat, organic soils, and roots) and total above-ground biomass (above-ground litter and live biomass). Diameters of woody fuels have been classified according to their "time-lag", which refers to the length of time that a fuel element takes to respond to a new moisture content equilibrium (Bradshaw et al., 1983). The time lag categories traditionally used for fire behavior are specified as $1,10,100$, and $1000 \mathrm{~h}$, and correspond to round woody fuels in the size ranges of $0-0.635,0.635-2.54,2.54$ 7.62 , and $7.62-20.32 \mathrm{~cm}$, respectively. In this study, we used US fire management standards to classify fuels into three different categories: (1) ground (all materials lying beneath 
Fuel Consumption field measurement locations

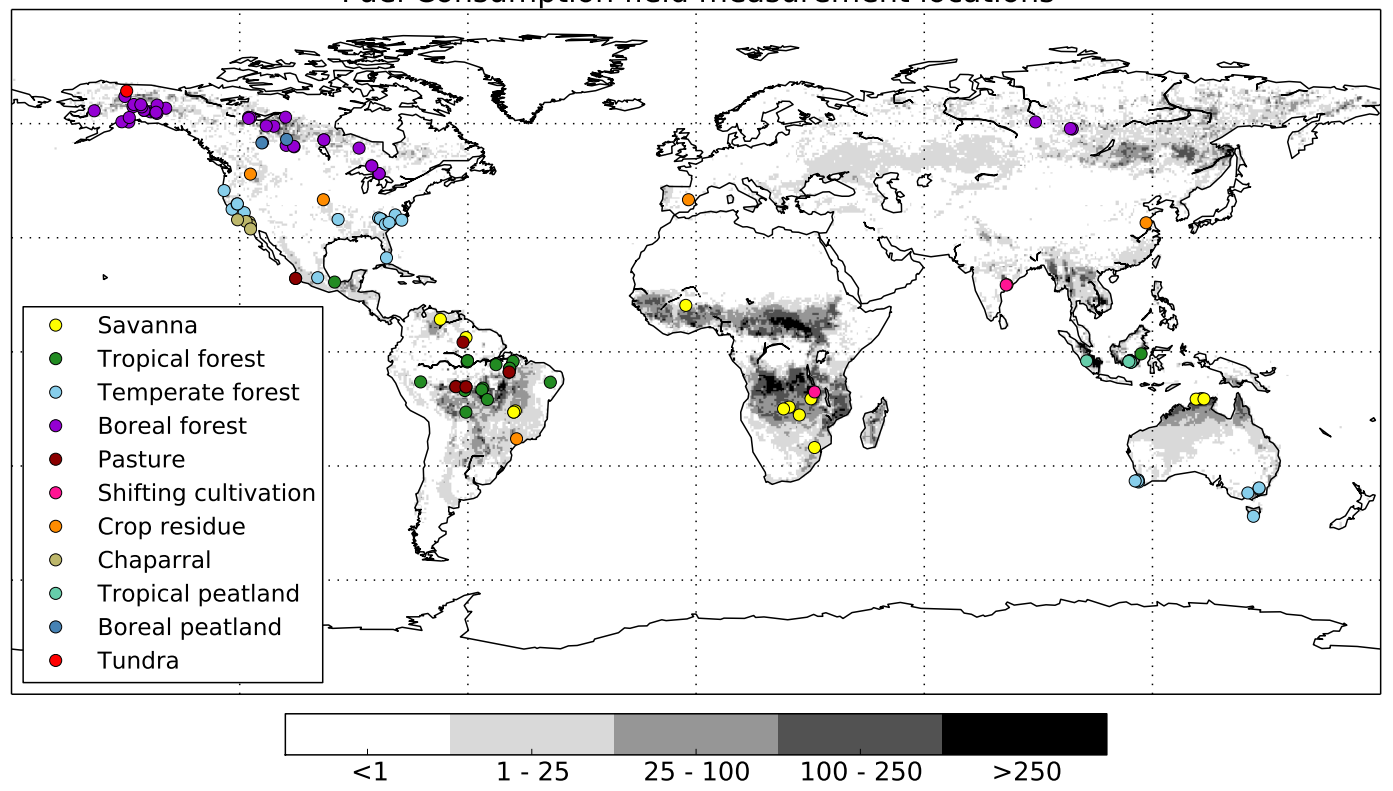

Figure 1. Fuel consumption field measurement locations for different biomes. Background map shows annual GFED3 fire C emissions in $\mathrm{g} \mathrm{C} \mathrm{m}^{-2}$ year $^{-1}$, averaged over 1997-2009.

the surface, including organic soil, roots, rotten buried logs, and other woody fuels), (2) surface (all materials lying on or immediately above the ground, including needles or leaves, grass, small dead wood, downed logs, stumps, large limbs, low brush, and reproduction) and (3) crown (aerial) fuel (all green and dead materials located in the upper forest canopy, including tree branches and crowns, snags, moss, and high brush).

Although a substantial body of grey literature of FC measurements is available, we focused on peer-reviewed studies. An exception was made for a few reports that focus on measurements conducted in the boreal forest and chaparral biome, because these reports were extensive and cited in peer-reviewed literature. Because the available data from peer-reviewed literature were obtained from a wide variety of sources spanning multiple decades, the reported FC data needed to be standardized. We converted all FC measurements to units of tons dry matter per hectare $\left(\mathrm{tha}^{-1}\right)$, which is the most commonly used unit. A carbon to dry matter conversion factor of 2 was used to convert carbon FC values to dry matter FC values. We note though that this conversion factor is not always representative of all biomes. Especially in the boreal regions - having a relative large contribution of organic soil fuels - but also in other biomes, this factor is sometimes lower, and therefore our approach may slightly overestimate FL and FC.

In Table 1 we present the FL, CC, and FC data compiled for 11 different biomes that are frequently used in global fire emissions assessments (e.g., van der Werf et al., 2010; Wiedinmeyer et al., 2011; Kaiser et al., 2012; Randerson et al., 2012). Some studies provided data for specific fuel classes (e.g., ground fuels) only, while others estimated a total FC for both the below- and above-ground biomass. The data presented in Table 1 focused on FC. Additional studies on FL measurements exist and were not included here, but are listed in a spreadsheet that is available online at http://www.falw.vu/ gwerf/FC. These estimates were extensive, mostly for southern Africa (e.g., Scholes et al., 2011) and Australia (e.g., Rossiter et al., 2003). Including these additional field measurements may change regional FL averages. More specific details on the measurements and different fuel categories for each biome are listed in Sects. 2.1-2.11.

\subsection{Savanna}

Savanna fires in the tropics can occur frequently, in some cases annually. Their FL consists mainly of surface fuels (like grass and litter from trees), and is influenced both by rainfall of the previous years and the time since the last fire (Gill and Allan, 2008). Traditionally, (African) savannas are split into dry and wet forms (Menaut et al., 1995). This split occurs at a precipitation rate of about $900 \mathrm{~mm}$ year $^{-1}$. Most savanna fires burn due to human ignition, but it is believed that these systems are seldom ignition limited, and more often limited by available fuel (Archibald et al., 2010). Fire incidence generally increases after years of above-average rainfall, especially in dry savannas with low population densities (van Wilgen et al., 2004; Russell-Smith et al., 2007). As these systems are generally fuel limited, grass production and consumption by herbivores are very important factors controlling the extent of area burned, particularly in drier regions 
Table 1. Location, fuel load (FL), combustion completeness (CC) and fuel consumption (FC) for field measurements conducted in the savanna (a), tropical forest (b), temperate forest (c), boreal forest (d), pasture (e), shifting cultivation (f), crop residue (g), chaparral (h), tropical peat (i), boreal peat (j), and tundra biome (k). Standard deviation (SD) is shown in parenthesis, and values indicated in bold were used to calculate the biome average.

\begin{tabular}{|c|c|c|c|c|c|c|c|}
\hline $\operatorname{Ref}^{\mathrm{a}}$ & $\begin{array}{r}\text { Lat. } \\
\left({ }^{\circ}\right)\end{array}$ & $\begin{array}{r}\text { Lon. } \\
\left({ }^{\circ}\right)\end{array}$ & Location & $\begin{array}{l}\text { FL } \\
\left(\text { tha }^{-1}\right)\end{array}$ & $\begin{array}{l}\mathrm{CC} \\
(\%)\end{array}$ & $\begin{array}{l}\mathrm{FC} \\
\left(\mathrm{tha}^{-1}\right)\end{array}$ & Description \\
\hline \multicolumn{8}{|l|}{ (a) } \\
\hline 1 & $12.35 \mathrm{~S}$ & $30.21 \mathrm{E}$ & Kasanka National Park, Zambia & $5.4(2.1)$ & $81(15)$ & $4.2(1.0)$ & Dambo, miombo, chitemene \\
\hline 1 & $16.60 \mathrm{~S}$ & $27.15 \mathrm{E}$ & Choma, Zambia & $5.1(0.4)$ & $88(2)$ & $4.5(-)$ & Semi-arid miombo \\
\hline 2 & $14.52 \mathrm{~S}$ & $24.49 \mathrm{E}$ & Kaoma local forest, Zambia & $5.8(3.8)$ & $53(32)$ & $2.2(1.2)$ & Dambo and miombo \\
\hline 4 & $12.22 \mathrm{~N}$ & $2.70 \mathrm{~W}$ & Tiogo state forest, Senegal & $5.8(1.6)$ & 75 (15) & $4.2(0.7)$ & Grazing and no grazing \\
\hline 5 & $15.84 \mathrm{~S}$ & $47.95 \mathrm{~W}$ & Brasilia, Brazil & $8.3(1.3)$ & $88(13)$ & $7.2(0.9)$ & Different types of cerrado \\
\hline 6 & $8.56 \mathrm{~N}$ & $67.25 \mathrm{~W}$ & Calaboza, Venezuela & $6.9(2.3)$ & $82(17)$ & $5.5(1.9)$ & Protected savanna for 27 years \\
\hline 7 & $15.51 \mathrm{~S}$ & $47.53 \mathrm{~W}$ & Brasilia, Brazil & $8.3(-)$ & $90(-)$ & $7.5(-)$ & Campo limpo and campo sujo \\
\hline 8 & $15.84 \mathrm{~S}$ & $47.95 \mathrm{~W}$ & Brasilia, Brazil & $8.9(3.1)$ & $92(4.1)$ & $8.2(2.8)$ & Different types of cerrado \\
\hline 9 & $3.75 \mathrm{~N}$ & $60.50 \mathrm{~W}$ & Roraima, Brazil & $6.1(3.6)$ & $56(27)$ & $2.6(0.9)$ & Different types of cerrado \\
\hline 14 & $12.38 \mathrm{~S}$ & $133.55 \mathrm{E}$ & Arnhem Plateau, Australia & $8.5(-)$ & $39(-)$ & $4.8(-)$ & Grass and open woodland \\
\hline 15 & $17.65 \mathrm{~N}$ & $81.75 \mathrm{E}$ & Kortha Valasa and Kudura, India & $35(6.4)$ & $22(7.7)$ & $7.7(2.6)$ & Woodland \\
\hline \multicolumn{8}{|l|}{ (b) } \\
\hline 5 & $4.30 \mathrm{~S}$ & $49.03 \mathrm{~W}$ & Marabá, Pará, Brazil & $207(-)$ & $48(-)$ & $103(-)$ & Primary and secondary forest \\
\hline 16 & $2.29 \mathrm{~S}$ & $60.09 \mathrm{~W}$ & Fazenda Dimona, Manaus, Brazil & $265(-)$ & $29(-)$ & $77(-)$ & 200 ha clearing for pasture \\
\hline 17 & $7.98 \mathrm{~S}$ & $38.32 \mathrm{~W}$ & Serra Talh., Pernambuco, Brazil & $74(0.2)$ & $87(8.6)$ & $64(6.4)$ & Second-growth tropical dry forest \\
\hline 18 & $4.50 \mathrm{~S}$ & $49.01 \mathrm{~W}$ & Marabá, Pará, Brazil & $364(-)$ & $52(-)$ & $190(-)$ & Cleared for pastures \\
\hline 18 & $15.85 \mathrm{~S}$ & $60.52 \mathrm{~W}$ & Santa Barbara, Rondônia, Brazil & $326(-)$ & $50(-)$ & $166(-)$ & Cleared for shifting cultivation \\
\hline 19 & $2.61 \mathrm{~S}$ & $60.17 \mathrm{~W}$ & Manaus, Brazil & $425(-)$ & $25(-)$ & $107(-)$ & Tropical dense rainforest \\
\hline 20 & $9.11 \mathrm{~S}$ & $63.16 \mathrm{~W}$ & Jamari, Rondônia, Brazil & $377(31)$ & $50(4.5)$ & $191(33)$ & Primary forest slash \\
\hline 27 & $9.52 \mathrm{~S}$ & $56.06 \mathrm{~W}$ & Alta floresta, Mato Grosso, Brazil & $496(-)$ & 39 (18) & $192(87)$ & 1,4, and 9 ha clearings \\
\hline 28 & $9.97 \mathrm{~S}$ & $56.34 \mathrm{~W}$ & Alta floresta, Mato Grosso, Brazil & $306(-)$ & $24(-)$ & $73(-)$ & Primary forest, 4 ha \\
\hline 29 & $12.53 \mathrm{~S}$ & $54.88 \mathrm{~W}$ & Feliz Natal, Mato Grosso, Brazil & $219(-)$ & $71(-)$ & $155(-)$ & Seasonal semi-deciduous forest \\
\hline 30 & $7.90 \mathrm{~S}$ & $72.44 \mathrm{~W}$ & Cruzeiro do Sul, Acre, Brazil & $583(-)$ & $39(-)$ & $226(-)$ & Primary forest, 4 ha clearing \\
\hline 31 & $18.35 \mathrm{~N}$ & $95.05 \mathrm{~W}$ & Los Tuxtlas, Mexico & $403(-)$ & $95(-)$ & $380(-)$ & Evergreen tropical forest \\
\hline 32 & $19.30 \mathrm{~N}$ & $105.3 \mathrm{~W}$ & San Mateo, Jalisco, Mexico & $127(-)$ & $71(-)$ & $91(-)$ & Tropical dry forest \\
\hline 33 & $0.52 \mathrm{~S}$ & $117.01 \mathrm{E}$ & East Kalimantan, Indonesia & 237 (106) & $56(24)$ & $120(47)$ & Lightly and heavily disturbed stands \\
\hline \multicolumn{8}{|l|}{ (c) } \\
\hline 34 & $34.80 \mathrm{~N}$ & $82.60 \mathrm{~W}$ & Southern Appalachians, USA & $110(-)$ & $59(-)$ & $65(-)$ & Mixed pine hardwoods \\
\hline 34 & $35.21 \mathrm{~N}$ & $83.48 \mathrm{~W}$ & Nantahala, N. Carolina, USA & $177(49)$ & $52(5.5)$ & $93(34)$ & Pine: jacob w. and e., devil den \\
\hline 34 & $36.00 \mathrm{~S}$ & $79.10 \mathrm{~W}$ & Hillsborough, N. Carolina, USA & $21(1.2)$ & $11(-)$ & $2.3(-)$ & Loblolly pine forest floor \\
\hline 34 & $34.80 \mathrm{~N}$ & $82.60 \mathrm{~W}$ & South East Piedmont, USA & - & - & $5.2(3.4)$ & Pinus taeda plantation, forest floor \\
\hline 34 & $37.50 \mathrm{~N}$ & $122.00 \mathrm{~W}$ & South East Coastal plain, USA & - & - & $15(9.1)$ & Pine forest floor \\
\hline 35 & $34.82 \mathrm{~N}$ & $94.13 \mathrm{~W}$ & Scott County, Arkansas, USA & $10(-)$ & $45(-)$ & $4.7(-)$ & Shortleaf pine grassland \\
\hline 36 & $36.60 \mathrm{~N}$ & $118.81 \mathrm{~W}$ & Sequoia National Park, USA & $230(-)$ & $92(-)$ & $212(-)$ & Mixed conifer trees \\
\hline 37 & $38.90 \mathrm{~N}$ & $120.67 \mathrm{~W}$ & Dark Canyon Creek, USA & $141(49)$ & $79(-)$ & $111(-)$ & Two week post fire \\
\hline 38 & $38.90 \mathrm{~N}$ & $120.62 \mathrm{~W}$ & Blodgett Forest, California, USA & $154(-)$ & $70(-)$ & $108(-)$ & Mixed conifer: moist and dry burn \\
\hline 39 & $24.73 \mathrm{~N}$ & $81.40 \mathrm{~W}$ & National Key Deer Refuge, USA & $23(5.9)$ & $57(11)$ & $13(4.3)$ & Pine forest, potential fuels \\
\hline 40 & $42.40 \mathrm{~N}$ & $124.10 \mathrm{~W}$ & Southwestern Oregon, USA & - & - & $39(-)$ & Mixed conifer forest \\
\hline 41 & $33.56 \mathrm{~N}$ & $81.70 \mathrm{~W}$ & Savannah River, USA & $19(-)$ & $55(-)$ & $11(-)$ & Mature loblolly, old longleaf pine \\
\hline 42 & $34.63 \mathrm{~N}$ & $77.40 \mathrm{~W}$ & Camp Lejeune, N. Carolina, USA & $11(3.8)$ & $45(29)$ & $5.6(4.7)$ & Pine understory \\
\hline
\end{tabular}


Table 1. Continued.

\begin{tabular}{|c|c|c|c|c|c|c|c|}
\hline $\operatorname{Ref}^{\mathrm{a}}$ & $\begin{array}{l}\text { Lat. } \\
\left({ }^{\circ}\right)\end{array}$ & $\begin{array}{l}\text { Lon. } \\
\left({ }^{\circ}\right)\end{array}$ & Location & $\begin{array}{l}\text { FL } \\
\left(\text { tha }^{-1}\right)\end{array}$ & $\begin{array}{l}\mathrm{CC} \\
(\%)\end{array}$ & $\begin{array}{l}\text { FC } \\
\left(\text { tha }^{-1}\right)\end{array}$ & Description \\
\hline \multicolumn{8}{|l|}{ (d) } \\
\hline 45 & $46.98 \mathrm{~N}$ & $83.43 \mathrm{~W}$ & Aubinadong River, ON, Canada & $99(4.2)$ & $66(5.4)$ & 34 (6.6) & Different depth classes used \\
\hline 46 & $46.78 \mathrm{~N}$ & $83.33 \mathrm{~W}$ & Sharpsand Creek, ON, Canada & $48(10)$ & $49(18)$ & 23 (7.6) & Immature jack pine \\
\hline 47 & $48.92 \mathrm{~N}$ & $85.29 \mathrm{~W}$ & Kenshoe Lake, ON, Canada & $332(-)$ & $7.5(-)$ & $24(-)$ & Surface and crown \\
\hline 48 & $63.38 \mathrm{~N}$ & $158.25 \mathrm{~W}$ & Innoko, Alaska, USA & - & - & $37(7.0)$ & Black spruce forest/shrub/bog \\
\hline 49 & $64.45 \mathrm{~N}$ & $148.05 \mathrm{~W}$ & Rosie Creek, Alaska, USA & - & - & 83 & Ground fuels \\
\hline 49 & $60.43 \mathrm{~N}$ & $149.17 \mathrm{~W}$ & Granite Creek, Alaska, USA & - & - & 30 & Ground fuels \\
\hline 49 & $67.14 \mathrm{~N}$ & $150.18 \mathrm{~W}$ & Porcupine, Alaska, USA & - & - & 25 & Ground fuels \\
\hline 49 & $63.12 \mathrm{~N}$ & $143.59 \mathrm{~W}$ & Tok River, Alaska, USA & - & - & 51 & Ground fuels \\
\hline 49 & $63.45 \mathrm{~N}$ & $145.12 \mathrm{~W}$ & Dry Creek, Alaska, USA & - & - & 41 & Ground fuels \\
\hline 49 & $63.08 \mathrm{~N}$ & $142.30 \mathrm{~W}$ & Tetlin, Alaska, USA & - & - & 56 & Ground fuels \\
\hline 49 & $63.50 \mathrm{~N}$ & $145.15 \mathrm{~W}$ & Hajdukovich Creek, Alaska, USA & - & - & 129 & Ground fuels \\
\hline 50 & $61.60 \mathrm{~N}$ & $117.20 \mathrm{~W}$ & Fort Providence, NT, Canada & $83(10)$ & $44(7.6)$ & $36(5.8)$ & Jack pine and black spruce \\
\hline 51 & $65.10 \mathrm{~N}$ & $147.30 \mathrm{~W}$ & Alaska, USA & - & - & $19(1.7)$ & Forest floor \\
\hline 52 & $64.40 \mathrm{~N}$ & $145.74 \mathrm{~W}$ & Delta Junction, Alaska, USA & $75(-)$ & $48(-)$ & $35(-)$ & Ground fuels: (non)-permafrost \\
\hline 53 & $53.92 \mathrm{~N}$ & $105.70 \mathrm{~W}$ & Montreal Lake, SK, Canada & $43(4.0)$ & $62(7.5)$ & $26(3.9)$ & Spruce, pine, mixed wood \\
\hline 54 & $65.03 \mathrm{~N}$ & $147.85 \mathrm{~W}$ & Fairbanks, Alaska, USA & $95(17)$ & $61(17)$ & 57 (19) & Differently facing slopes \\
\hline 55 & $46.87 \mathrm{~N}$ & $83.33 \mathrm{~W}$ & Sharpsand Creek, ON, Canada & $13(2.0)$ & $69(32)$ & $9(4.0)$ & Experimental fire: forest floor \\
\hline 55 & $48.87 \mathrm{~N}$ & $85.28 \mathrm{~W}$ & Kenshoe Lake, ON, Canada & $17(3.0)$ & $35(13)$ & $6(2.0)$ & Experimental fire: forest floor \\
\hline 55 & $61.37 \mathrm{~N}$ & $117.63 \mathrm{~W}$ & Fort Providence, NT, Canada & $47(9.0)$ & $36(9.0)$ & $17(3.0)$ & Experimental fire: forest floor \\
\hline 55 & $61.69 \mathrm{~N}$ & $107.94 \mathrm{~W}$ & Porter Lake, NT, Canada & $15(0.0)$ & $60(20)$ & $9(3.0)$ & Experimental fire: forest floor \\
\hline 55 & $55.07 \mathrm{~N}$ & $114.03 \mathrm{~W}$ & Hondo, AB, Canada & $3(1.0)$ & 33 (35) & $1(1.0)$ & Experimental fire: forest floor \\
\hline 55 & $59.31 \mathrm{~N}$ & $111.02 \mathrm{~W}$ & Darwin Lake, NT, Canada & $18(3)$ & $72(20)$ & $13(3.0)$ & Experimental fire: forest floor \\
\hline 55 & $55.74 \mathrm{~N}$ & $97.91 \mathrm{~W}$ & Burntwood River, MB, Canada & $72(12)$ & $26(8.0)$ & $19(5.0)$ & Wildfire: forest floor \\
\hline 55 & $54.29 \mathrm{~N}$ & $107.78 \mathrm{~W}$ & Green Lake, SK, Canada & $36(13)$ & $86(54)$ & $31(16)$ & Wildfire: forest floor \\
\hline 55 & $53.57 \mathrm{~N}$ & $88.62 \mathrm{~W}$ & Kasabonika, ON, Canada & $69(19)$ & $55(46)$ & $38(30)$ & Wildfire: forest floor \\
\hline 55 & $55.74 \mathrm{~N}$ & $97.85 \mathrm{~W}$ & Thompson, MB, Canada & $23(14)$ & $87(63)$ & $20(8.0)$ & Wildfire: forest floor \\
\hline 55 & $54.05 \mathrm{~N}$ & $105.81 \mathrm{~W}$ & Montreal Lake, SK, Canada & $61(41)$ & $57(47)$ & 35 (17) & Wildfire: forest floor \\
\hline 55 & $64.06 \mathrm{~N}$ & $139.43 \mathrm{~W}$ & Dawson City, YT, Canada & $84(30)$ & $46(31)$ & $39(22)$ & Wildfire: forest floor \\
\hline 55 & $59.40 \mathrm{~N}$ & $113.03 \mathrm{~W}$ & Wood Buffalo Nat. Pk., Canada & $37(9.0)$ & $59(35)$ & $22(12)$ & Wildfire: forest floor \\
\hline 56 & $60.49 \mathrm{~N}$ & $150.98 \mathrm{~W}$ & Soldotna, Alaska, USA & $91(22)$ & $37(5.2)$ & $33(4.8)$ & Mystery creek 1-3 \\
\hline 56 & $61.61 \mathrm{~N}$ & $149.04 \mathrm{~W}$ & Palmer, Alaska, USA & $84(4.2)$ & $61(3.5)$ & $51(5.7)$ & Deshka 1-2 \\
\hline 56 & $62.69 \mathrm{~N}$ & $141.77 \mathrm{~W}$ & Tetlin Refuge, Alaska, USA & $105(16)$ & $45(15)$ & $49(20)$ & Tetlin, chisana 1-4 \\
\hline 56 & $64.87 \mathrm{~N}$ & $147.71 \mathrm{~W}$ & Fairbanks, Alaska, USA & $86(16)$ & $36(23)$ & $32(22)$ & Bonanza creek, frostfire \\
\hline 57 & $63.00 \mathrm{~N}$ & $142.00 \mathrm{~W}$ & Alaska, USA & $152(-)$ & $59(-)$ & $90(-)$ & Black spruce forest \\
\hline 58 & $65.00 \mathrm{~N}$ & $146.00 \mathrm{~W}$ & Alaska, USA & $72(-)$ & $58(-)$ & $40(-)$ & Black spruce forest \\
\hline 59 & $60.45 \mathrm{~N}$ & $89.25 \mathrm{E}$ & Bor, Krasnoyarsk, Russia & $34(-)$ & $50(-)$ & $17(-)$ & Pine-lichen forest and litter \\
\hline 60 & $58.58 \mathrm{~N}$ & $98.92 \mathrm{E}$ & Lower Angara, Russia & $54(12)$ & $31(15)$ & $17(8.6)$ & Scots pine, larch mixed wood \\
\hline 60 & $58.70 \mathrm{~N}$ & $98.42 \mathrm{E}$ & Lower Angara, Russia & $43(-)$ & $42(-)$ & $18(-)$ & Scots pine, larch mixed wood \\
\hline \multicolumn{8}{|l|}{ (e) } \\
\hline 20 & $9.17 \mathrm{~S}$ & $63.18 \mathrm{~W}$ & Jamari, Rondônia, Brazil & $66(13)$ & $31(10)$ & $21(17)$ & 12 year old pasture site \\
\hline 61 & $5.30 \mathrm{~S}$ & $49.15 \mathrm{~W}$ & Fransico, Pará, Brazil & $53(4.8)$ & $83(-)$ & $44(-)$ & Two slash fires prior to burning \\
\hline 61 & $9.20 \mathrm{~S}$ & $60.50 \mathrm{~W}$ & João and Durval, Rondônia, Brazil & $96(-)$ & $34(-)$ & $30(-)$ & 4 year old pasture site \\
\hline 62 & $2.54 \mathrm{~N}$ & $61.28 \mathrm{~W}$ & Vila de Apiau, Roraíma, Brazil & $119(-)$ & $20(-)$ & $24(-)$ & Pasture and forest \\
\hline 32 & $19.30 \mathrm{~N}$ & $105.3 \mathrm{~W}$ & San Mateo, Jalisco, Mexico & $35(-)$ & $69(-)$ & $23(-)$ & High and low severity \\
\hline \multicolumn{8}{|l|}{ (f) } \\
\hline 63 & $10.53 \mathrm{~S}$ & $31.14 \mathrm{E}$ & Kasama, Zambia & $75(-)$ & $64(-)$ & $43(-)$ & Shifting cultivation \\
\hline 64 & $17.59 \mathrm{~N}$ & $81.55 \mathrm{E}$ & Damanapalli and Velegapalli, India & $14(-)$ & $30(-)$ & $4.0(-)$ & Shifting cultivation in dry forest \\
\hline \multicolumn{8}{|l|}{ (g) } \\
\hline 65 & $40.00 \mathrm{~N}$ & $2.00 \mathrm{~W}$ & Spain, Europe & $1.4(-)$ & $80(-)$ & $1.1(-)$ & Cereal crops \\
\hline 66 & $22.85 \mathrm{~S}$ & $47.60 \mathrm{~W}$ & Piracicaba, Sao Paulo, Brazil & - & - & $20(-)$ & Sugar cane \\
\hline 67 & $33.94 \mathrm{~N}$ & $118.33 \mathrm{E}$ & Suqian, China & $6.7(1.2)$ & 44 (4.6) & $2.9(0.5)$ & Mix (wheat, rice, corn, potato) \\
\hline 68 & $40.00 \mathrm{~N}$ & $98.00 \mathrm{E}$ & North America & $2.4(3.6)$ & $86(6.0)$ & $2.1(3.2)$ & Mix of crop types \\
\hline 68 & $46.73 \mathrm{~N}$ & $117.18 \mathrm{E}$ & North America & $12(-)$ & $90(-)$ & $11(-)$ & Seedgrass \\
\hline \multicolumn{8}{|l|}{ (h) } \\
\hline 69 & $34.10 \mathrm{~N}$ & $117.47 \mathrm{~W}$ & Lodi Canyon, California, USA & - & - & $45(-)$ & Prescribed chaparral fire \\
\hline 70 & $33.33 \mathrm{~N}$ & $117.16 \mathrm{~W}$ & Bear Creek, California, USA & $60(5.9)$ & $83(6.0)$ & $50(8.4)$ & Mature caenothus and chamise \\
\hline 70 & $34.29 \mathrm{~N}$ & $118.33 \mathrm{~W}$ & Newhall, California, USA & $20(6.7)$ & $75(4.0)$ & $15(5.4)$ & Mature chamise \\
\hline 70 & $32.32 \mathrm{~N}$ & $117.15 \mathrm{~W}$ & TNC, California, USA & $21(-)$ & $77(-)$ & $16(-)$ & Young and healthy chamise \\
\hline 42 & $34.73 \mathrm{~N}$ & $120.57 \mathrm{~W}$ & Vandenberg, California, USA & $14(-)$ & $68(-)$ & $10(-)$ & Coastal sage and maritime chaparral \\
\hline
\end{tabular}


Table 1. Continued.

\begin{tabular}{|c|c|c|c|c|c|c|c|}
\hline $\operatorname{Ref}^{\mathrm{a}}$ & $\begin{array}{l}\text { Lat. } \\
\left({ }^{\circ}\right)\end{array}$ & $\begin{array}{r}\text { Lon. } \\
\left({ }^{\circ}\right)\end{array}$ & Location & $\begin{array}{l}\text { FL } \\
\left(\mathrm{tha}^{-1}\right)\end{array}$ & $\begin{array}{l}\mathrm{CC} \\
(\%)\end{array}$ & $\begin{array}{l}\mathrm{FC} \\
\left(\mathrm{tha}^{-1}\right)\end{array}$ & Description \\
\hline \multicolumn{8}{|l|}{ (i) } \\
\hline 71 & $2.52 \mathrm{~S}$ & $113.79 \mathrm{E}$ & Kalimantan, Indonesia & - & - & $500(-)$ & Peat and overstory \\
\hline 72 & $2.50 \mathrm{~S}$ & $114.17 \mathrm{E}$ & Palangka Raya, Indonesia & 399 (11) & $27(4.7)$ & 109 (19) & Various peat fire fuels \\
\hline 73 & $2.37 \mathrm{~S}$ & $102.68 \mathrm{E}$ & Pelawan, Riau, Indonesia & $45(6.1)$ & $81(10)$ & $37(8.2)$ & Litter and branches \\
\hline 74 & $2.52 \mathrm{~S}$ & $113.79 \mathrm{E}$ & Kalimantan, Indonesia & - & - & $332(6.4)$ & Measured by LIDAR \\
\hline \multicolumn{8}{|l|}{ (j) } \\
\hline 75 & $55.85 \mathrm{~N}$ & $107.67 \mathrm{~W}$ & Patuanak, Canada & - & - & $42(25)$ & Continental and permafrost bogs \\
\hline 76 & $54.93 \mathrm{~N}$ & $114.17 \mathrm{~W}$ & Chisholm, Canada & - & - & $43(-)$ & Hummocks and hollows \\
\hline \multicolumn{8}{|l|}{ (k) } \\
\hline 77 & $68.58 \mathrm{~N}$ & $149.72 \mathrm{~W}$ & Anaktuvuk River, Alaska, USA & $165(15)$ & $24(5.0)$ & $40(9.0)$ & Soil and plants \\
\hline $\begin{array}{l}\text { Medina } \\
\text { Rossiter- } \\
\text { Kauffma } \\
\text { et al. (19 } \\
\text { Carvalhs } \\
\text { Finney ( } \\
\text { al. (2013 } \\
\text { et al. (20 } \\
\text { Ottmar a } \\
\text { (t62) Bar } \\
\text { et al. (20 }\end{array}$ & $\begin{array}{l}\text { et al. (2014 } \\
\text { 2); (37) Bêe } \\
\text { 43) Hollis e } \\
\text {; (50) Stock } \\
\text { Sandberg (2) }\end{array}$ & $\begin{array}{l}\text { (31) Hughes et } \\
\text { e et al. (2005); } \\
\text { al. (2010); (44) } \\
\text { et al. (2004); (5 } \\
\text { 10); (57) Turets } \\
\text { de (1996); (63) }\end{array}$ & 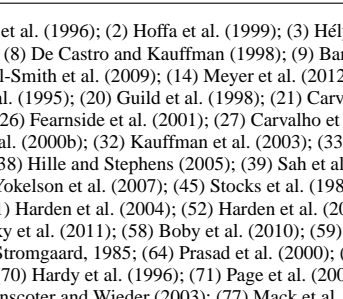 & $\begin{array}{l}\text { yet al. (2003b } \\
\text { bosa and Fear } \\
\text { ); (15) Prasad } \\
\text { alho et al. (19 } \\
\text { al. (2001); (28 } \\
\text { Toma et al. ( } \\
\text { (2006); (40) } \\
\text { 7a); (46) Stoc } \\
\text { O6); (53) de C } \\
\text { FrRESCAN S } \\
\text { 65) Zarate et : } \\
\text { 2); (72) Usup }\end{array}$ & $\begin{array}{l}\text { (4) Savadog } \\
\text { side (2005); } \\
\text { tal. (2001); } \\
\text { ); (22) Graç } \\
\text { Christian et } \\
\text { o5); (34) Ca } \\
\text { ampbell et a } \\
\text { et al. (1987 } \\
\text { oot et al. (20 } \\
\text { ience Team } \\
\text { (2005); (66 }\end{array}$ & $\begin{array}{l}\text { et al. (2007); } \\
\text { 0) Cook et al. } \\
\text { 6) Fearnside et } \\
\text { et al. (1999); ( } \\
\text {,2007/Soares } \\
\text { er et al. (2004) } \\
\text { (2007); (41) G } \\
\text {; (407) Stocks ( } \\
\text { 7); (54) Kane e } \\
\text { 996); (600) Ivan } \\
\text {-ara et al. (200 }\end{array}$ & $\begin{array}{l}\text { ) Ward et al. (1992); (6) Bilbao and } \\
\text { 1994); (11) Hurst et al. (1994); (12) } \\
\text { al. (1993); (17) Kauffman et al. (1993); (18) } \\
\text { 3) Fearnside et al. (1999); (24) Araújo } \\
\text { Jeto et al. (2009); (29) Righi et al. (2009); (30) } \\
\text { (35) Sparks et al. (2002); (36) Stephens and } \\
\text { odrick et al. (2010); (42) Yokelson et } \\
\text { 9199); (48) Goode tel al. (2000); (49) Kasischke } \\
\text { al. (2007); (55) de Groot et al. (2009); (56) } \\
\text { va et al. (2011); (61) Kauffman et al. (1998); } \\
\text { ); (67) Yang et al. (2008); (68) McCarty } \\
\text { Nurhayati (2006); (74) Ballhorn et al. (2009); }\end{array}$ \\
\hline
\end{tabular}

where rainfall can vary strongly between years (Menaut et al., 1991; Cheney and Sullivan, 1997; Russell-Smith et al., 2007). Grass production controls fire spread because lowbiomass grasslands have less continuous fuel swards and also because they burn at lower intensities, which reduces the probability of spread. In wet savannas, the grass production is poorly correlated with rainfall and much higher than in dry savannas (10 to $20 \mathrm{tha}^{-1}$ year $^{-1}$, Gignoux et al., 2006). This results in higher-intensity fires, keeping the landscape relatively open. In Australia, the division into dry and wet savannas is less clear. Annual grass production is typically low (less than $3 \mathrm{tha}^{-1}$ year $^{-1}$ ), even for precipitation rates of $2000 \mathrm{~mm}_{\text {year }}{ }^{-1}$. This difference is mostly due to the fact that Australia's native grasses are limited by nitrogen availability at high rainfalls, something African grasses such as Andropogon gayanus overcome through various mechanisms (Rossiter-Rachor et al., 2009).

Miombo woodlands in Africa are high-rainfall savannas where up to $40 \%$ of the fuel can be provided by litter from trees (Frost et al., 1996). A similar type of vegetation can be found in Brazil, mainly consisting of woodlands with a closed canopy of tall shrubs and scattered trees (Cerrado denso). We found several measurements conducted in Miombo woodlands, as well as field measurements in the Brazilian Cerrado denso. Moreover, one study was found for an Indian deciduous forest, which can be classified as wooded savanna and thus the savanna biome (Ratnam et al., 2011).

To calculate averages, we divided the savanna biome into grassland savanna and wooded savanna by using the fuel type description that was provided in each study. The savanna measurements presented in Table 1a were taken between
1990 and 2009, and represent 17 unique measurement locations (Fig. 1) taken from 15 different studies. For all measurements conducted, we found an average FL of $7.6 \pm 6.5 \mathrm{tha}^{-1}$ and FC of $4.6 \pm 2.2 \mathrm{tha}^{-1}$. The average of the $\mathrm{CC}$ values as presented in the different studies indicated a value of $71 \pm 26 \%$, higher than the ratio derived from the average FL and FC (61\%) above. This difference is because not all FC measurements reported FL. Within the savanna biome, regional differences were found (Fig. 2): FL and FC for South American savannas, $8.2 \pm 1.6$ and $6.0 \pm 2.4 \mathrm{tha}^{-1}$, respectively, were nominally higher than the ones measured in the savannas of Australia (5.1 \pm 2.2 and 3.6 $\left.\pm 1.6 \mathrm{tha}^{-1}\right)$. Measurements conducted in Africa, contributing to roughly $40 \%$ of all measurements in the biome, showed the lowest FC $\left(3.4 \pm 1.0 \mathrm{t} \mathrm{ha}^{-1}\right)$ of all regions. A larger number of measurements are required to say conclusively whether these differences are statistically significant. To show the difference between grassland savannas and wooded savannas, data of both types of savanna are also provided in Fig. 2. For grassland savannas the average FL was relatively low $\left(5.3 \pm 2.0 \mathrm{tha}^{-1}\right)$ and the CC high $(81 \pm 16 \%)$, yielding an average $\mathrm{FC}$ of $4.3 \pm 2.2 \mathrm{tha}^{-1}$. Wooded savannas, on the other hand, had a higher FL $\left(11 \pm 9.1 \mathrm{tha}^{-1}\right)$ but lower CC $(58 \pm 32 \%)$, and therefore the average FC of $5.1 \pm 2.2 \mathrm{tha}^{-1}$ was only slightly higher than the one found for grasslands.

In Table 2 these values are given for different fuel categories. For the savanna biome most of the fuels were classified as surface fuels (Table 2a). In general, fuels with a large surface-area-to-volume ratio (like litter, grass and dicots) had a high CC of at least $88 \%$. CC values were significantly lower for the woody debris classes, with a minimum of $21 \pm 12 \%$ found for woody fuels with a diameter larger than 
$2.54 \mathrm{~cm}(100 \mathrm{~h}$ fuel). FC for the different fuel types was between 0.3 and $1.9 \mathrm{tha}^{-1}$, with litter having the highest values. In general, the total sum of different fuel categories agrees well with the biome-averaged values presented. However, not all measurements distinguished between fuel categories and therefore small discrepancies were sometimes found: for FC in the savanna biome, for example, the sum of different fuel categories is $5.3 \mathrm{tha}^{-1}$, slightly higher than the biome average of $4.6 \pm 2.2 \mathrm{tha}^{-1}$.

\subsection{Tropical forest}

Tropical evergreen forests are generally not susceptible to fire except during extreme drought periods (e.g., Field et al., 2009; Marengo et al., 2011; Tomasella et al., 2013) due to their dense canopy cover keeping humidity high and wind speed low, and also because the amount of fuel on the surface is low due to rapid decomposition. Human activities have resulted in fire activity in tropical forests, often with the goal to clear biomass and establish pasture or cropland. These deforestation fires can be small-scale (e.g., shifting cultivation, discussed in Sect. 2.6) or on a large scale with the aid of heavy machinery. In the latter case, biomass is often piled in windrows after the first burn and subject to additional fires during the same dry season to remove the biomass more completely. In large-scale deforestation regions like the state of Mato Grosso in the Brazilian Amazon, the expansion of mechanized agriculture could result in increased fuel consumed per unit area (Cardille and Foley, 2003; Yokelson et al., 2007a). All these fires, but also selective logging, may lead to more frequent accidental fires as fragmented forests are more vulnerable to fire (Nepstad et al., 1999; Siegert et al., 2001; Pivello, 2011).

The total FL in tropical forests is mostly determined by the tree biomass (surface and canopy fuels) and generally on the order of a few hundred tha ${ }^{-1}$. CC depends partly on the size of the clearing and on the curing period. In general, the CC for tropical forest clearings is lower than $50 \%$ (Balch et al., 2008), but when there is a long (more than a year) lag between slash and burning the CC might increase to $60 \%$ and more (Carvalho et al., 2001). The El Niño-Southern Oscillation (ENSO) phenomenon may also have a large effect on fuel conditions over tropical regions. Large-scale fires have been shown to occur in South America, Southeast Asia, and Africa in ENSO years, thereby likely increasing CC due to drought conditions (Chen et al., 2011; Field et al., 2009; Hély et al., 2003a).

The 22 unique measurement locations shown in Table $1 \mathrm{~b}$ cover Brazil (19), Mexico (2), and Indonesia (1). In general, measurement sites were divided into several smaller subplots and the forest was slashed at the beginning of the dry season. The biomass was then weighed using the PIM. After about 2 months the plots were set on fire and the remaining biomass was weighed within 1 week after the burn. The average FL for the whole biome was $285 \pm 137 \mathrm{tha}^{-1}, \mathrm{CC}$ averaged
$49 \pm 22 \%$, and total FC was $126 \pm 77 \mathrm{tha}^{-1}$. Since more than $90 \%$ of all measurements were conducted in Brazil (Fig. 3), the biome-averaged values are biased towards measurements conducted there. Studies conducted in Mexican and Indonesian tropical forests reported average FL of 265 and $237 \mathrm{tha}^{-1}$, respectively. Surprisingly, the CC of tropical forest in Mexico was the highest of all the studies $(83 \%$ on average), resulting in an average $\mathrm{FC}$ of $236 \mathrm{t} \mathrm{ha}^{-1}$, which was significantly higher than values found for both Brazil $\left(117 \pm 56 \mathrm{tha}^{-1}\right)$ and Indonesia $\left(120 \pm 47 \mathrm{tha}^{-1}\right)$. However, due to the small number of measurements conducted in Mexico and Indonesia, these findings are not conclusive.

Different forest types may partly explain the discrepancy found, and therefore we distinguished between measurements conducted in primary tropical evergreen forest, secondary tropical evergreen forest, and tropical dry forest (Fig. 3). To distinguish between tropical dry forests and wooded savannas (Sect. 2.1), we harmonized with the emission factor compilation of Akagi et al. (2011) in which $60 \%$ canopy cover (Hansen et al., 2003) was the delineation between both ecosystems. FL and FC were largest for primary tropical evergreen forests, with average values of $339 \pm 104$ and $143 \pm 79 \mathrm{tha}^{-1}$, respectively. For secondary tropical evergreen forests these values were substantially lower $\left(101 \pm 32\right.$ and $\left.57 \pm 7.0 \mathrm{tha}^{-1}\right)$ and comparable with tropical dry forests in South America and Mexico, where the average FL was 100 and the FC $78 \mathrm{tha}^{-1}$.

Different fuel categories for the tropical forest biome are presented in Table $2 \mathrm{~b}$ and can be mainly classified as surface fuels, except for the attached foliage (crown fuels) and rootmat category (ground fuels). Large woody debris (diameter $>20.5 \mathrm{~cm}$ ) and trunks - although not always taken into account in certain studies - correspond to a large part of the above-ground biomass ( $\mathrm{FL}=147 \pm 83 \mathrm{tha}^{-1}$ ) but are usually only slightly burned during a forest clearing process (Carvalho et al., 1995), as shown by an average CC of $32 \pm 23 \%$ leading to an FC of this category of only $37 \pm 32 \mathrm{tha}^{-1}$. Similar to the savanna biome, we found a high CC of at least $73 \%$ for surface fuels with a large surface area to volume ratio (litter, leaves, and dicots). The small woody fuels (1 and $10 \mathrm{~h}$ ) also had a high CC, and the CC of the woody debris generally decreased with increasing diameter. From an FC perspective, the most important fuel types in the tropical forest biome were litter $\left(14 \pm 8.4 \mathrm{tha}^{-1}\right)$ and woody debris size classes with a diameter larger than $0.64 \mathrm{~cm}$ $\left(15-37 \mathrm{tha}^{-1}\right)$.

\subsection{Temperate forest}

Although accounting for only a small part of the global emissions, temperate forest fires frequently occur nearby the wildland-urban interface with important consequences for human safety and air quality. While tropical fires are largely intentionally ignited to pursue land management goals, the temperate forest is also subject to wildfires. Obtaining FC 
Table 2. Fuel load (FL), combustion completeness (CC) and fuel consumption (FC) field measurements for different fuel categories within the savanna (a), tropical forest (b), temperate forest (c), and boreal forest (d) biomes. Standard deviation (SD) is shown in parentheses.

\begin{tabular}{|c|c|c|c|c|c|}
\hline $\mathrm{Cl}^{\mathrm{a}}$ & Fuel category & $\begin{array}{l}\text { FL } \\
\left(\text { tha }^{-1}\right)\end{array}$ & $\begin{array}{l}\mathrm{CC} \\
(\%)\end{array}$ & $\begin{array}{l}\mathrm{FC} \\
\left(\mathrm{tha}^{-1}\right)\end{array}$ & References $^{b}$ \\
\hline \multicolumn{6}{|l|}{ (a) } \\
\hline $\mathrm{S}$ & Dicots & $0.4(0.5)$ & $91(12)$ & $0.3(0.3)$ & $1,2,5$ \\
\hline $\mathrm{S}$ & Grass-dormant & $1.9(1.4)$ & $93(14)$ & $1.3(0.5)$ & $1,2,5$ \\
\hline $\mathrm{C}$ & Grass-green & $0.4(0.2)$ & $88(23)$ & $0.3(0.1)$ & $1,2,5$ \\
\hline $\mathrm{S}$ & Litter & $2.1(0.5)$ & $88(13)$ & $1.9(0.5)$ & $1,2,5,8,12,15$ \\
\hline $\mathrm{S}$ & Tree/shrub leaves & $0.4(0.8)$ & $64(12)$ & $0.3(0.6)$ & $1,2,5$ \\
\hline$S$ & Woody debris $(0-0.64 \mathrm{~cm})$ & $0.6(0.7)$ & $65(16)$ & $0.4(0.5)$ & $1,2,5,8$ \\
\hline $\mathrm{S}$ & Woody debris $(0.64-2.54 \mathrm{~cm})$ & $0.9(1.0)$ & $39(25)$ & $0.5(0.7)$ & $1,2,5,8$ \\
\hline $\mathrm{S}$ & Woody debris $(>2.54 \mathrm{~cm})$ & $1.0(1.1)$ & $21(12)$ & $0.3(0.3)$ & $1,2,5,8$ \\
\hline \multicolumn{6}{|l|}{ (b) } \\
\hline $\mathrm{C}$ & Attached foliage & $3.8(3.0)$ & $94(5.1)$ & $3.6(2.8)$ & $5,18,20,25,32$ \\
\hline $\mathrm{S}$ & Dicots & $0.5(0.3)$ & $89(23)$ & $0.5(0.3)$ & $5,18,20,25,32$ \\
\hline$S$ & Leaves & $13(8.8)$ & $73(38)$ & $11(9.8)$ & $16,17,19,21,24,27,28,29$ \\
\hline$S$ & Litter & $18(9.9)$ & $85(30)$ & $14(8.4)$ & $5,17-29,32$ \\
\hline $\mathrm{S}$ & Liana & $5.2(0.8)$ & $21(35)$ & $0.9(1.4)$ & $19,21,24$ \\
\hline G & Rootmat & $5.2(2.7)$ & $87(13)$ & $4.4(2.2)$ & $18,20,25$ \\
\hline $\mathrm{S}$ & Woody debris $(0-0.64 \mathrm{~cm})$ & $4.6(2.8)$ & $94(4.8)$ & $6.4(8.6)$ & $5,17,18,20,25,32$ \\
\hline $\mathrm{S}$ & Woody debris $(0.65-2.54 \mathrm{~cm})$ & $17(3.9)$ & $87(7.9)$ & $15(4.0)$ & $5,17,18,20,25,32$ \\
\hline $\mathrm{S}$ & Woody debris $(2.55-7.6 \mathrm{~cm})$ & $27(15)$ & $65(19)$ & $18(13)$ & $5,17,18,20,25,32$ \\
\hline $\mathrm{S}$ & Woody debris $(7.6-20.5 \mathrm{~cm})$ & $45(29)$ & $41(18)$ & $18(9.3)$ & $5,17,18,20,25,32$ \\
\hline $\mathrm{S}$ & Woody debris $(>20.5 \mathrm{~cm})$, trunks & $147(83)$ & $32(23)$ & $37(32)$ & $5,16,18-23,26-30$ \\
\hline \multicolumn{6}{|l|}{ (c) } \\
\hline G & Organic soil & $49(37)$ & $48(44)$ & $25(31)$ & $34,37,38$ \\
\hline $\mathrm{S}$ & Litter & $20(11)$ & $81(8.9)$ & $17(9.9)$ & $34,37,38$ \\
\hline $\mathrm{S}$ & Woody debris $(0-0.64 \mathrm{~cm})$ & $1.2(0.8)$ & $87(11)$ & $1.0(0.6)$ & $36,37,38$ \\
\hline $\mathrm{S}$ & Woody debris $(0.65-2.54 \mathrm{~cm})$ & $5.2(1.9)$ & $79(11)$ & $4.0(1.2)$ & $36,37,38$ \\
\hline $\mathrm{S}$ & Woody debris $(2.55-7.6 \mathrm{~cm})$ & $6.0(0.9)$ & $73(14)$ & $4.3(0.2)$ & $36,37,38$ \\
\hline $\mathrm{S}$ & Woody debris $(7.6-20.5 \mathrm{~cm}$ sound $)$ & $16(9.6)$ & $38(42)$ & $6.2(8.2)$ & $36,37,38$ \\
\hline G & Woody debris $(7.6-20.5 \mathrm{~cm}$ rotten) & $20(4.1)$ & $96(5.4)$ & $20(4.8)$ & $36,37,38$ \\
\hline \multicolumn{6}{|l|}{ (d) } \\
\hline $\mathrm{G}$ & Ground fuels (soil, forest floor) & $50(29)$ & $51(18)$ & $32(26)$ & $44,48,49,50,51,53,54,55,57,58$ \\
\hline $\mathrm{S}$ & Surface fuels & $44(49)$ & $52(25)$ & $12(8.1)$ & $44,46,49,52,55,58,59$ \\
\hline $\mathrm{C}$ & Crown fuels & $37(70)$ & $71(29)$ & $8.1(6.9)$ & $44,46,49,57,59$ \\
\hline \multicolumn{6}{|c|}{$\begin{array}{l}\text { Fuel category classification: } \mathrm{S}=\text { surface fuels, } \mathrm{G}=\text { ground fuels, C= crown fuels. } \\
\text { References: (1) Shea et al. (1996)/Ward et al. (1996); (2) Hoffa et al. (1999); (5) Ward et al. (1992); (8) De Castro and Kauffman (1998); } \\
\text { (12) Rossiter-Rachor et al. (2007); (15) Prasad et al. (2001); (16) Fearnside et al. (1993); (17) Kauffman et al. (1993); (18) Kauffman et al. (1995); (19) } \\
\text { Carvalho et al. (1995); (20) Guild et al. (1998); (21) Carvalho et al. (1998); (22) Graça et al. (1999); (23) Fearnside et al. (1999); (24) Araújo et al. (1999) } \\
\text { (25) Hughes et al. (2000a); (26) Fearnside et al. (2001); (27) Carvalho et al. (2001); (28) Christian et al. (2007)/Soares Neto et al. (2009); (29) Righi } \\
\text { et al. (2009); (30) Carvalho Jr. et al. (2014); (32) Kauffman et al. (2003); (34) Carter et al. (2004); (36) Stephens and Finney (2002); (37) Bêche } \\
\text { et al. (2005); (38) Hille and Stephens (2005); (45) Stocks et al. (1987a); (47) Stocks (1989); (49) Kasischke et al. (2000); (50) Stocks et al. (2004); (51) } \\
\text { Harden et al. (2004); (52) Harden et al. (2006); (53) de Groot et al. (2007); (54) Kane et al. (2007); (55) de Groot et al. (2009); (56) Ottmar and } \\
\text { Sandberg (2010); (58) Boby et al. (2010); (59) FIRESCAN Science Team (1996); (60) Ivanova et al. (2011). }\end{array}$} \\
\hline
\end{tabular}

measurements for wildfires is obviously challenging, so most information is derived from prescribed fires that allow researchers to measure pre-fire conditions. However, these fires may not always be a good proxy for wildfires. For example, wildfires in western conifer forests of the US are often crown fires (while prescribed fires usually only burn surface fuels).
Due to potential discrepancies with respect to FC, we distinguished between these fire types in Sect. 3.2.

The 23 unique FC measurement locations for the temperate forest are from sites in North America (14), Australia (7), Tasmania (1) and Mexico (1), and were taken between 1983 and 2011 (Fig. 1). In general, measurements were conducted on sites that were divided into multiple, randomized subplots 

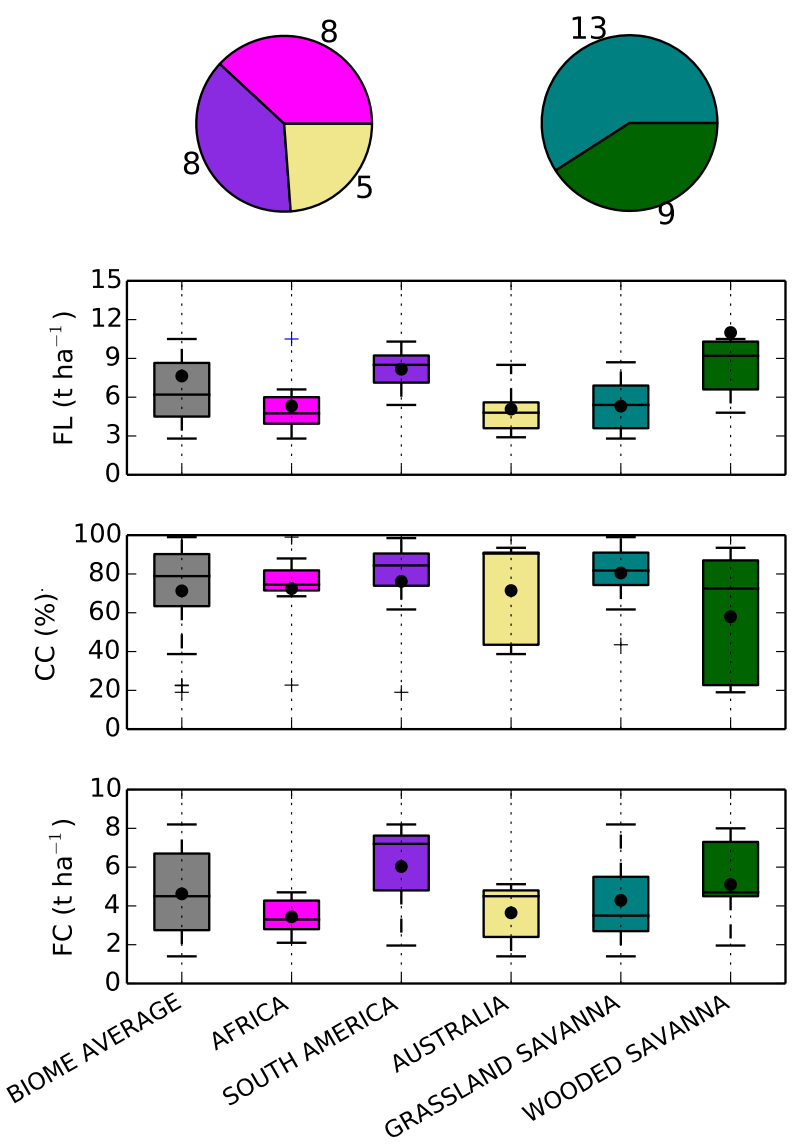

Figure 2. Overview of field measurements of fuel load (FL), combustion completeness (CC), and fuel consumption (FC) in the savanna biome. The pie charts on top correspond to the number of unique measurement locations for different geographical regions (left) and savanna types (right), and in the box plots below field averages of FL, CC, and FC are presented. The boxes extend from the lower to upper quartile values of the measurement data, with a line at the median and a black filled circle at the mean. The whiskers extend from the box to show the range of the data, and outliers are indicated with pluses.

on which the pre-fire biomass was weighed according to the PIM. The sites were then burned and within a few days after the burn the post-fire biomass was gathered, dried and weighed.

The biome-averaged FL for the temperate forest biome was $115 \pm 144 \mathrm{tha}^{-1}$, the CC equaled $61 \pm 18 \%$, and fuel consumed by the fire was $58 \pm 72 \mathrm{tha}^{-1}$. Note that we focused on all the measurements presented in Table 1c, so studies that provide information on one specific fuel class only (e.g., ground fuels, Goodrick et al., 2010) were also included to calculate biome-averaged values. Although CC for North America, Australia and Tasmania were comparable $(\sim 60 \%)$, the FC showed lower values for North America $\left(49 \pm 62 \mathrm{tha}^{-1}\right)$ than Australia and Tasmania $\left(78 \pm 91 \mathrm{tha}^{-1}\right)$. One possible cause of this discrepancy
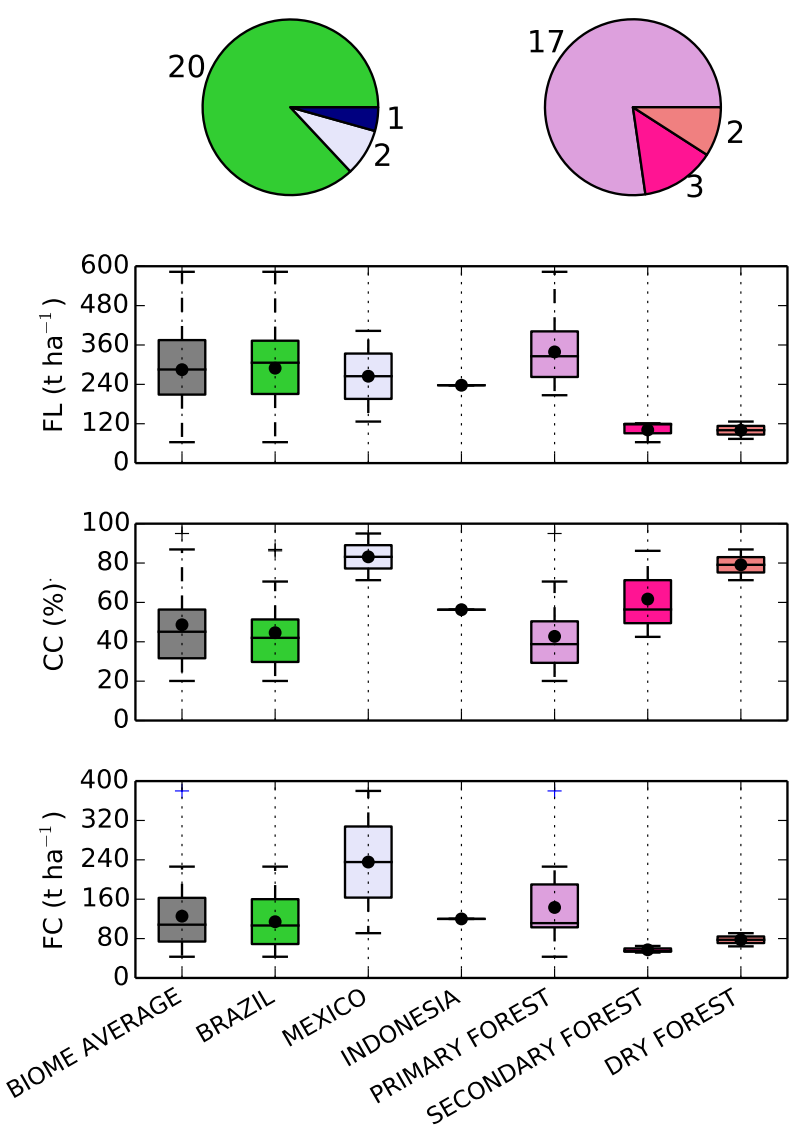

Figure 3. Overview of field measurements of fuel load (FL), combustion completeness (CC), and fuel consumption (FC) in the tropical forest biome. The pie charts on top correspond to the number of unique measurement locations for different geographical regions (left) and forest types (right), and in the box plots below field averages of FL, CC, and FC are presented. The boxes extend from the lower to upper quartile values of the measurement data, with a line at the median and a black filled circle at the mean. The whiskers extend from the box to show the range of the data, and outliers are indicated with pluses.

is the contribution of different vegetation types, as elaborated in Fig. 4. Measurements in North America were mainly conducted in conifer forest, while eucalypt was the more dominant forest type for Australia and Tasmania. FC for both forest types compares fairly well with the regional averages found, and equaled $48 \pm 58 \mathrm{tha}^{-1}$ for conifers and $79 \pm 98 \mathrm{tha}^{-1}$ for eucalypt forest.

Table 2c shows that litter in the temperate forest had a higher FL and FC than in the tropical forest biome, and the average $\mathrm{FC}$ for this surface fuel category equaled $17 \pm 9.9 \mathrm{tha}^{-1}$. The different woody debris classes had a similar pattern to that found for the savanna and tropical forest biome, with decreasing $\mathrm{CC}$ for categories with increasing fuel diameters. However, an interesting difference was found in the biggest size class: sound woody debris had a low CC (38 $\pm 42 \%)$, while the fraction of rotten woody 

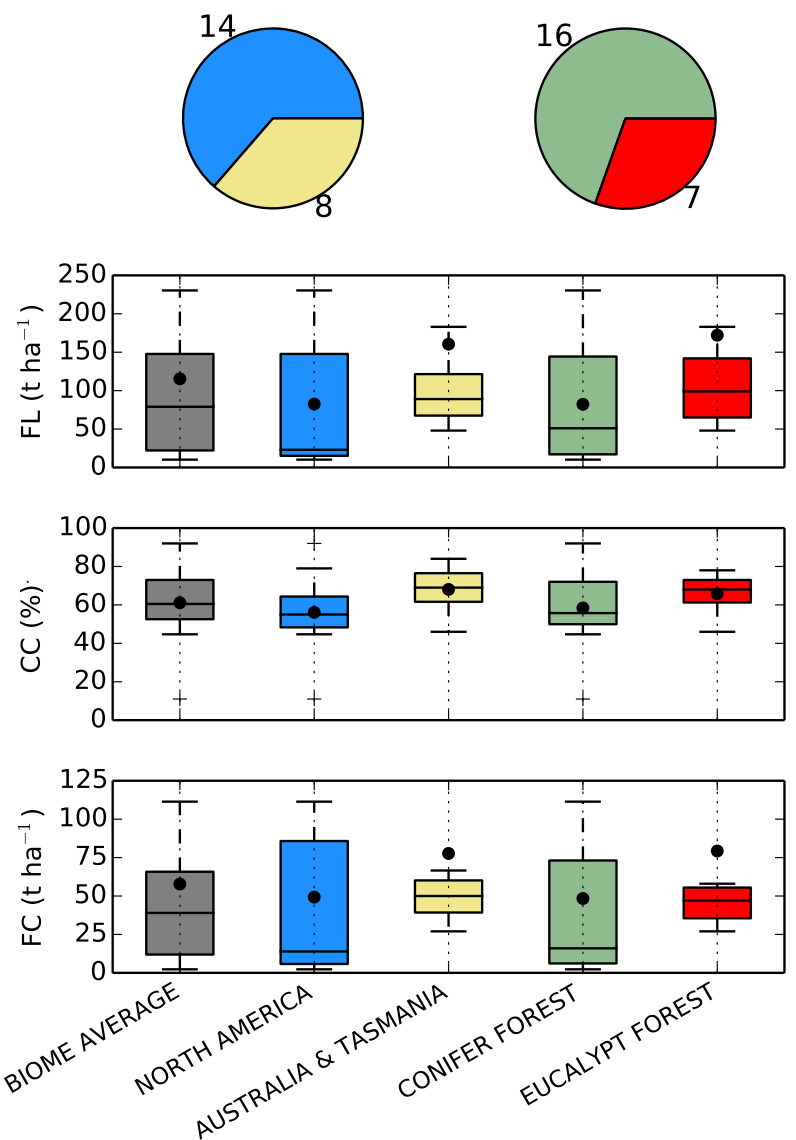

Figure 4. Overview of field measurements of fuel load (FL), combustion completeness (CC), and fuel consumption (FC) in the temperate forest biome. The pie charts on top correspond to the number of unique measurement locations for different geographical regions (left) and forest types (right), and in the box plots below field averages of FL, CC, and FC are presented. The boxes extend from the lower to upper quartile values of the measurement data, with a line at the median and a black filled circle at the mean. The whiskers extend from the box to show the range of the data, and outliers are indicated with pluses.

debris consumed by the fire was very high $(96 \pm 5.4 \%)$, resulting in an average FC of $20 \pm 4.8 \mathrm{tha}^{-1}$ for this category. Although this difference was observed in a few other studies as well, little research is available on comparing the physical and chemical properties of sound and rotten woody debris, which is likely to affect the FC (Hyde et al., 2011). The most important fuel category from an FC perspective was organic soil, with an average value of $25 \pm 31 \mathrm{tha}^{-1}$. For the same reason as explained in Sect. 2.1, a small discrepancy was found between the total FC sum of different fuel categories $\left(77 \mathrm{tha}^{-1}\right)$ and the biome average $\left(58 \pm 72 \mathrm{tha}^{-1}\right)$.

\subsection{Boreal forest}

Fires in the boreal (high latitudes of about 50 to $70^{\circ}$ ) forest are thought to be mostly natural (wildfires) due to the vast
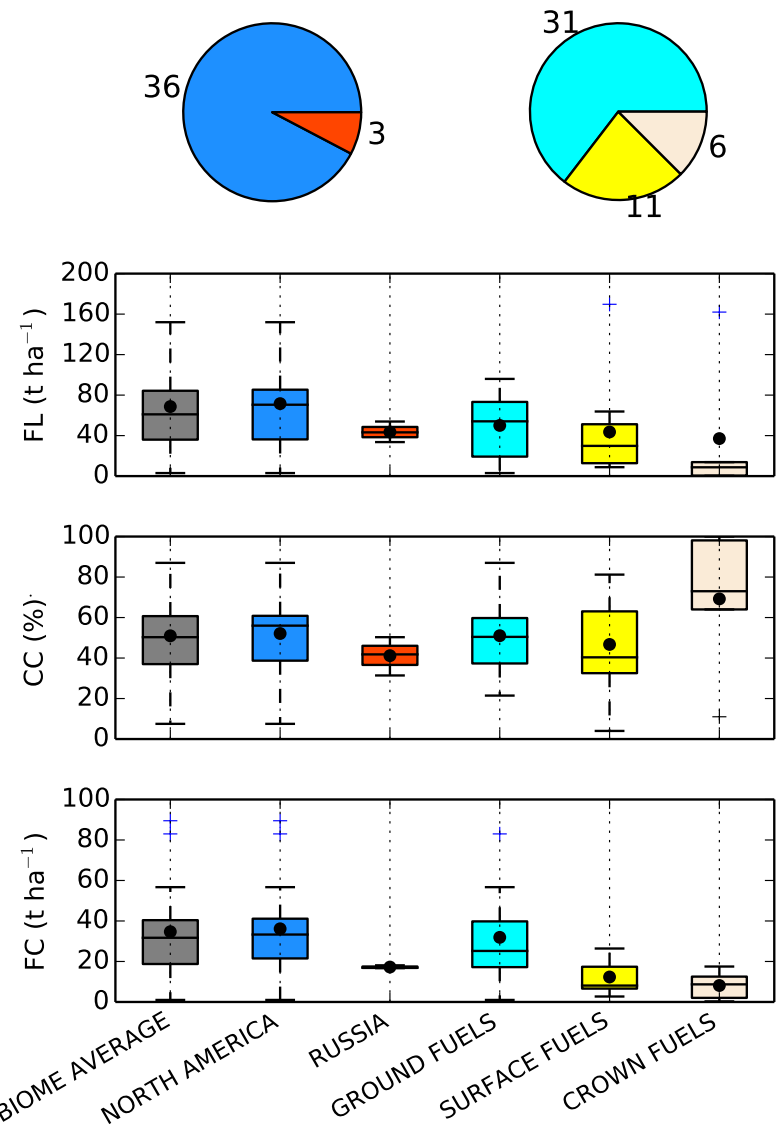

Figure 5. Overview of field measurements of fuel load (FL), combustion completeness (CC), and fuel consumption (FC) in the boreal forest biome. The pie charts on top correspond to the number of unique measurement locations for different geographical regions (left) and fuel classes (right), and in the box plots below field averages of FL, CC, and FC are presented. The boxes extend from the lower to upper quartile values of the measurement data, with a line at the median and a black filled circle at the mean. The whiskers extend from the box to show the range of the data, and outliers are indicated with pluses.

size of the forest region, the low population densities and the difficult accessibility. However, much of the Asian boreal forests are disturbed by (il)legal logging activities (Vandergert and Newel, 2003), which can increase fire activity in more remote regions (Mollicone et al., 2006). Approximately two thirds of the boreal forests are located in northern Eurasia, while the remainder is in North America. The circumpolar boreal fire regime is characterized by large forest fires, although fires in North America are in general larger and less frequent than the ones in Eurasia (de Groot et al., 2013a). North American boreal fires are characterized by high intensity crown fires, while fires in boreal Russia are more often surface fires of lower intensity (Amiro et al., 2001; Soja et al., 2004; Wooster et al., 2004; de Groot et al., 2013a). Canada has a very long fire record, starting in 1959 , while the record 
for Alaska starts in 1950 (Kasischke et al., 2002). Since 1990, 2.65 million ha year ${ }^{-1}$ burned in the North American boreal forest, with high year-to-year variability (Kasischke et al., 2011). FL in the boreal forests depends to a large extent on tree species, stand density, climate, topography, moisture, seasonal thawing of permafrost and the time since the last burn. In many forest types, dead material accumulates in deep organic soil horizons due to the slow decomposition rates. CC in organic soils is mostly controlled by conditions that control surface soil moisture, including topography, seasonal thawing of permafrost, and antecedent weather conditions. When dry conditions prevail, such as during a highpressure blocking event that can last for few days to several weeks over North America (Nash and Johnson, 1996), much of the forest floor can burn, and depths of $30 \mathrm{~cm}$ or more can be reached. There is a strong relation between moisture content and fuel bed depth on the one hand and forest floor consumption on the other hand (e.g., de Groot et al., 2009). Of all global fire regimes, the boreal forest is most susceptible to climate change due to polar amplification of temperature increase (Flannigan et al., 2013; de Groot et al. 2013b). For example, the area burned by lightning fires in the North American boreal region doubled between 1960 and 1990 (Kasischke and Turetsky, 2006).

Field measurements described in the literature were almost all conducted in boreal North America (35 in total), except for three measurement sets that came from boreal Asia (Fig. 1, Table 1d). The general method for determining FL and FC was to apply the PIM. Approaches have also been developed to estimate consumption of surface organic layer fuels by estimating the pre- and post-fire thicknesses and densities of surface organic horizons (de Groot et al., 2009; Turetsky et al., 2011).

We estimated a biome-averaged FL of $69 \pm 61 \mathrm{tha}^{-1}$, substantially lower than the average FL for the temperate forests. The average FL for this biome is for upland forest types. However, deep peatland deposits (see Sect. 2.10) cover about $107 \mathrm{M}$ ha (Zoltai et al., 1998) or $18 \%$ of the North American boreal forest zone (Brandt, 2009) and $16 \%$ of the northern circumpolar permafrost soil area (Tarnocai et al., 2009). By contrast, peatlands only cover about $0.07 \mathrm{M}$ ha in the temperate zone, which has higher FL overall. Despite low decomposition rates due to a cold, moist climate, the lower FL in the boreal forest region is primarily a result of slower tree growth rates (biomass accumulation) and frequent to infrequent fire disturbance that can remove substantial amounts of fuel. The average CC was $51 \pm 17 \%$, and the FC equaled $35 \pm 24 \mathrm{tha}^{-1}$. Similar as for the temperate forest, we included all measurements (presented in Table 1d) to calculate the biome-averaged values. The representativeness of these values for wildfires and prescribed fires is discussed in Sect. 3.2. Differences between boreal North America and Siberia were observed, but it should be noted that only three studies provided an FC estimate for Russia. Values on FL,
CC, and FC were overall higher for boreal fires in North America than the field studies in Russia (Fig. 5).

Information on fuel categories is presented in Table 2d, as well as in Fig. 5. Different classification systems were sometimes used for boreal fuels, and therefore it was difficult to extract the right information for ground, surface and crown fuels (further discussed in Sect. 3.4). Moreover, it was not always clear in which class certain fuels are consumed: e.g., organic material can be consumed on the ground but also in a crown fire (Hille and Stephens, 2005). The highest FL $\left(50 \pm 29 \mathrm{tha}^{-1}\right)$ and FC $\left(32 \pm 26 \mathrm{tha}^{-1}\right)$ in the boreal forest biome was found for ground fuels, mainly consisting of organic soils. Furthermore, a difference in organic matter FL in permafrost and non-permafrost regions was found (56 and $86 \mathrm{tha}^{-1}$, respectively). However, due to a CC of 62 and $41 \%$ for permafrost and non-permafrost regions, the FC for both regions was equal $\left(35 \mathrm{tha}^{-1}\right)$. Finally, slope aspect has been shown to have an effect as well, with the south facing slopes having the highest FL and FC due to warmer and drier conditions that better favour plant growth and fire intensity than shadowed north faces (Viereck et al., 1986; Turetsky et al., 2011). As with most of our findings, however, the number of studies is far too low to evaluate whether this is also the case in general.

\subsection{Pasture}

Fires related to agricultural practices were divided into shifting cultivation (Sect. 2.6), the burning of crop residues (Sect. 2.7) and pasture burning. The latter type of burning often follows tropical deforestation fires and is used to convert land into pasture. Prior to this conversion, lands can be used in shifting cultivation as well. Typically, landowners set fires every 2-3 years to prevent re-establishment of forests (Kauffman et al., 1998) and to enhance the growth of certain grasses (Fearnside, 1992). In general, these fires mostly consume grass and residual wood from the original forest. Pasture fires are most common in the Brazilian Amazon where many cattle ranches have been established in areas that were previously tropical forest. Although less abundant, these "maintenance" fires also occur in tropical regions of Africa, central America and Asia.

The pasture measurements presented in Table 1e represent five unique measurement locations and cover two different continents (Fig. 1). Pasture had an average FL, CC, and FC of $74 \pm 34 \mathrm{tha}^{-1}, 47 \pm 27 \%$, and $28 \pm 9.3 \mathrm{tha}^{-1}$, respectively. Regional discrepancies for FC were found though, with FL for Brazilian pastures $\left(84 \pm 29 \mathrm{tha}^{-1}\right)$ being substantially higher than those found in Mexico $\left(35 \mathrm{tha}^{-1}\right)$. However, FC values compared reasonably well for both regions $(30 \pm 10$ and $24 \mathrm{tha}^{-1}$ for Brazil and Mexico, respectively). 


\subsection{Shifting cultivation}

Shifting cultivation is commonly practiced in Africa, central America, South America and Asia. In general, lands are cultivated temporarily (often for only a few years) before soil fertility is exhausted or weed growth overwhelms the crops. The lands are then abandoned and may revert to their natural vegetation, while the farmers move on to clear a new fields elsewhere. The land is slashed and burned, which leaves only stumps and large trees in the field after the fire (Stromgaard, 1985). Apart from the fact that fire is an easy and cheap tool to clear the land, it has the further advantage that the ashes will also (temporarily) enrich the soil.

For shifting cultivation fires the average FL was 44 with a range of 14-75 tha $\mathrm{th}^{-1}$, the CC equaled 47 [30-64]\%, and $\mathrm{FC}$ was 23 [4-43] tha ${ }^{-1}$. Note that these values are based on the measurements of two studies only (Fig. 1, Table 1f). The two shifting cultivation studies showed a remarkable difference: FC of Indian tropical dry deciduous forest $\left(4.0 \mathrm{tha}^{-1}\right.$; Prasad et al., 2000) was 1 order of magnitude lower than for shifting cultivation practices in the wooded savanna of Zambia (43 $\mathrm{tha}^{-1}$; Stromgaard, 1985). Due to the relatively small number of measurements, these findings are not conclusive.

\subsection{Crop residue}

Crop residue burning is a common practice to recycle nutrients, control pests, diseases, and weeds and, in general, to prepare fields for planting and harvesting. The main crop residue types that burn are rice, grains (i.e., wheat) and sugarcane, but burning is not limited to these crop types. FL is highly variable, as it depends on both the type of crop burned and the method used for harvesting the crop (mechanized, manual, etc.). Detecting these fires using global burned area products is difficult, as in general, cropland fires are small and the land can be tilled and replanted quickly after burning (making it difficult to observe the latency of burned ground as is common in less managed and/or more natural landscapes). Moreover, the fuel geometry varies globally from short-lived burning of loose residue in the field to long-lasting smoldering combustion of small hand piles of residue, and both are hard to detect from space. Traditional methods of obtaining estimates for agricultural fires are the use of governmental statistics on crop yield (e.g., Yevich and Logan, 2003), residue usage for cooking and livestock (the leftovers are assumed to be burned), field measurements, or the use of agronomic data (e.g., Jenkins et al., 1992).

On average, crop residue burning had FL of $8.3 \pm 9.9 \mathrm{tha}^{-1}, \mathrm{CC}$ of $75 \pm 21 \%$ and FC of $6.5 \pm 9.0 \mathrm{tha}^{-1}$ (Table 1g). We estimated an average FL of $23 \mathrm{tha}^{-1}$ for Brazilian sugarcane (Lara et al., 2005) by using a CC of $88 \%$ as reported by McCarty et al. (2011). FC values for different US crop types (McCarty et al., 2011) were used to derive crop-specific FL data (French et al., 2013) and CC values were taken from expert knowledge from agriculture

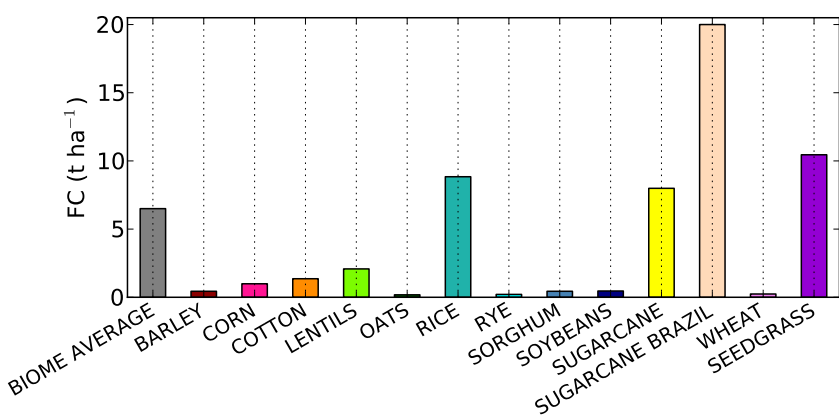

Figure 6. Fuel consumption (FC) for different US crop types as reported by McCarty et al. (2011), and Brazilian sugarcane (Lara et al., 2005). The grey bar corresponds to the biome-averaged FC value for crop residue burning as presented in this study.

extension agents in Arkansas, Louisiana, Florida, Kansas, and Washington during field campaigns in 2004, 2005, and 2006, as well as from the scientific literature (Dennis et al., 2002; Johnston and Golob, 2004). CC variables ranged from $65 \%$ for cotton and sugarcane and $85 \%$ for wheat and bluegrass, which are lower but within the range of the $\mathrm{CC}$ value ( -23 to $-3 \%$ less than $\mathrm{CC}$ of $88 \%$ ) used by the Environmental Protection Agency (EPA) of $88 \%$ (EPA 2008 GHG).

FC values varied between different crop types, as shown in Fig. 6. For US crops the highest FC was found for seedgrass $\left(10 \mathrm{tha}^{-1}\right)$ and rice $\left(8.8 \mathrm{tha}^{-1}\right)$, while values for soybeans $\left(0.5 \mathrm{tha}^{-1}\right)$ and corn $\left(1.0 \mathrm{tha}^{-1}\right)$ were lower. In general, US crop values are assumed in the analysis to be approximately representative of other developed agricultural areas like Brazil and Russia (McCarty et al., 2012), but uncertainty increases for less industrialized agricultural areas in Africa and Asia. However, Brazilian sugarcane $\left(20 \mathrm{tha}^{-1}\right)$ was found to have an FC that is more than twice as high as sugarcane in the US $\left(8.0 \mathrm{tha}^{-1}\right)$. More measurements are needed to confirm this discrepancy.

\subsection{Chaparral}

Chaparral vegetation is a type of shrubland that is primarily found in the southwestern US and in the northern portion of Baja California (Mexico), but similar plant communities are found in other Mediterranean climate regions around the world like Europe, Australia and South Africa. Typically, the Mediterranean climate is characterized by a moderate winter and dry summer, which makes the chaparral biome most vulnerable to fires in summer and fall (Jin et al., 2014). In California, the combination of human ignition, the large wildland-urban interface, and extreme fire weather characterized by high temperatures, low humidities, and high offshore Santa Ana winds (Moritz et al., 2010) may lead to large and costly wildfires (Keeley et al., 2009).

We found two studies covering five different measurement locations in the southwestern US (Table 1, Fig. 1h). Since 
Cofer III et al. (1988) only provided an FC for chaparral burning, we used a CC of $76 \%$ (average CC from the studies of Hardy et al. (1996) and Yokelson et al., 2013) to derive an FL estimate for the Cofer et al. (1988) study. We then used the FL values of all three studies to estimate the biomeaveraged FL of $40 \pm 23 \mathrm{tha}^{-1}$. The CC equaled $76 \%$, yielding an average $\mathrm{FC}$ of $27 \pm 19 \mathrm{tha}^{-1}$.

\subsection{Tropical peat}

Tropical peatland has only recently been recognized as an important source of biomass burning emissions. Roughly $60 \%$ of the worldwide tropical peatland is located in Southeast Asia, and more specifically in Indonesia (Rieley et al., 1996; Page et al., 2007). Peat depth is an indicator for the total biomass stored in peatland, but only the peat layer above the water table can burn. Drainage and droughts lower the water table, adding to the total FL. On top of that, living biomass and dead above ground organic matter also contribute to the FLs in these peatlands. The bulk density and carbon content of peat are of importance to determine the amount of carbon stored. The average density is around $0.1 \mathrm{~g} \mathrm{~cm}^{-3}$ and the carbon content ranges between 54-60\% (Page et al., 2002; Riely et al., 2008; Ballhorn et al., 2009; Stockwell et al., 2014). The depth of burning is the key factor that determines the total FC, but information about it is scarce. Results from several field measurements indicate a link between this burning depth and the depth of drainage (Ballhorn et al., 2009). Commercial logging in drained peat swamps has increased their susceptibility to fire, especially during droughts (such as during an ENSO event).

In total four studies provided data on tropical peatland measurements in Indonesia (Table 1i). In general, post-fire observations of the average burn depth were combined with pre-fire conditions reconstructed from adjacent unburned patches to determine the FC.

Tropical peatland (including peat soils and overstory) had the highest FC of all biomes, with an average of $314 \pm 196 \mathrm{tha}^{-1}$. Only two studies provided data on FL and CC, and since the study of Saharjo and Nurhayati (2006) focused on litter and branches only, a CC of $27 \%$ (Usup et al., 2004) was found to be representative for the tropical peat biome. Taking a CC of $27 \%$, the biome-averaged FL equaled $1056 \pm 876 \mathrm{tha}^{-1}$, thereby having the highest FL of all biomes. However, due to limited information on CC measured in the field there is no clear definition of the average FL for tropical peat. Note that the measurements taken by Ballhorn et al. (2009) were using Laser Imaging, Detection And Ranging (LIDAR) aerial remote sensing, and the study of Page et al. (2002) relied on field measurements combined with information obtained from Landsat Thematic Mapper (TM) images.

\subsection{Boreal peat}

The northern peatlands are a result of the slow decomposition of organic material over thousands of years. Traditionally, northern peatlands have been considered a slow, continuous carbon sink. However, the vulnerability of this region to global warming and the resulting increase in wildland fires have challenged this idea (Zoltai et al., 1998; Harden et al., 2000; Turetsky, 2002). There are still large uncertainties associated with the FL and CC of peat fires. The depth of fires is not well documented, leading to large uncertainties in the total FC estimates. In some cases, water table depth may serve as a proxy for determining the depth of burning. However, the susceptibility of peatlands to fire under different moisture conditions is also poorly documented at best. This makes modeling peat fires very difficult and stresses the importance of more field measurements.

Two measurements were taken between 1999 and 2001 in boreal Canada (Table 1j). On each burn site, multiple plots were established and information on the peat density (which is assumed to increase nonlinearly with depth) was used in combination with the burn depth to determine the FC. No data on FL and CC were provided, but the average FC of the two studies is 43 [42-43] $\mathrm{tha}^{-1}$. A standard deviation of $25 \mathrm{tha}^{-1}$ (Turetsky and Wieder, 2001) can be used as the average uncertainty for the boreal peat biome. Turetsky and Wieder (2001) showed that FC of permafrost bogs (58 [4372] $\left.\mathrm{tha}^{-1}\right)$ is more than twice as high as that of continental bogs (27 [11-42] tha $\left.{ }^{-1}\right)$. A similar difference was found for hummocks and hollows, which are raised peat bogs and lows, respectively: FC for hummocks was $29 \pm 2.0 \mathrm{tha}^{-1}$, while fires in hollows consumed on average $56 \pm 6.0 \mathrm{tha}^{-1}$ (Benscoter and Wieder, 2003).

\subsection{Tundra}

The Arctic tundra stores large amounts of carbon in its organic soil layers that insulate and maintain permafrost soils, although these soil layers are shallower than those found in peatlands and boreal forests. While the region is treeless, some vegetation types include a substantial shrub component where additional carbon is available for burning. On Alaska's North Slope approximately $10 \%$ of the land cover is shrub dominated ( $>50 \%$ shrub cover), while the remainder is dominated by herbaceous vegetation types (Raynolds et al., 2006). Fire regime in the Arctic is largely unknown, but historically fire is generally absent in the tundra biome compared to other biomes. However, the evidence of increasing fire frequency and larger extent of the fires in the arctic (Hu et al., 2010) may represent a positive feedback effect of global warming, so in the future more fires may occur in this biome (Higuera et al., 2011). There are still large unknowns of the impacts that fires have on the carbon stocks of the tundra ecosystems. Even the topsoil layers in the tundra store large pools of carbon in organic-rich material. This removal 
of the topsoil may also expose the permafrost layers to heating by the warm summer temperatures, thawing the ground and destabilizing the tundra carbon balance.

The only measurements found in the literature of $\mathrm{FC}$ in the tundra biome are from the Anaktuvuk River fire in 2007 (Mack et al., 2011). The measurements were taken on twenty sites in the burned area and the pre-fire peat layer depth was reconstructed to determine the pre-fire FL. The FL was on average $165 \pm 15 \mathrm{tha}^{-1}$, and averaged $\mathrm{CC}$ and total $\mathrm{FC}$ was respectively $24 \pm 5.0 \%$ and $40 \pm 9.0 \mathrm{tha}^{-1}$ (Table $1 \mathrm{k}$ ). These measurements represent a thorough effort to document FC, but still represent just one fire that is considered to be a fairly high severity event (Jones et al., 2009). Other measurements of surface FC at fires in the Noatak region of Alaska and a recent burn on the Alaskan North Slope showed minimal organic surface material loss (N. French, unpublished data). These fires may represent more typical fire events with more moderate consumption than was found in the Anaktuvuk River fire. There is no doubt that the lack of sufficient field measurements in the tundra biome means a reasonable estimate of FC in tundra fires is not fully known. While the Anaktuvuk River fire measurements are of value, there should be caution in using these data to generalize since the event represents a more severe event than many fires in the region. They may, however, be indicative of how future fires in the region may impact carbon losses as the region experiences increased fire frequency and severity.

\section{Discussion}

\subsection{Spatial representativeness of fuel consumption measured in the field}

Due to the spatial heterogeneity in fuels and the limited number of measurements, one important question to ask is how representative the biome-averaged values presented in this review are. Field measurements of FC were spatially well represented in the major biomass-burning regions, like the Brazilian Amazon, boreal North America and the savanna areas in southern Africa. However, several other regions that are important from a fire emissions perspective were lacking any measurements, and these include central Africa (e.g., Congo and Angola, but also regions further north such as Chad and southern Sudan), Southeast Asia and eastern Siberia (Fig. 1). Due to these spatial gaps, it remains uncertain whether measurements of FL, CC, and FC as presented in this study are representative for the whole biome. As mentioned for the "Tundra", where fire may become increasingly important as the region warms, the one set of field samples included in this review may not be representative of past and future fire.

Within biomes differences were found to be large for certain regions, as shown in Figs. 2-5. For example, we found substantial differences in FL and FC for boreal areas, with
Russian sites having lower values compared to the ones in North America (Fig. 5). This difference might be due to different burning conditions in both regions, with a larger contribution of surface fuels and less high-intensity crown fires occurring in boreal Russia (Wooster et al., 2004). Although available literature data showed that $\mathrm{FC}$ for crown fuels was indeed higher than for surface fuels, more data for especially boreal Russia is needed to confirm this line of thought. Moreover, Boby et al. (2010) and Turetsky et al. (2011) showed that the timing of FC measurements (early dry seasons versus late dry season) contribute to different boreal $\mathrm{FC}$ values as well. In general, both FC and CC may increase over the course of the dry season as large diameter fuels dry out. This was also suggested by Akagi et al. (2011) for the savanna biome, and is consistent with the seasonal decrease in MCE as proposed by Eck et al. (2013).

Regional differences were also found for the tropical forest biome, where almost all measurements were conducted in the Brazilian Amazon, with a few exceptions for Mexico and Indonesia. Southeast Asia (Myanmar, Vietnam, Laos, and Cambodia) was lacking any FC measurements described in the peer-reviewed literature, but this region is important from a fire emissions perspective. Tropical forests in Mexico had a higher CC than forests in the Amazon and Indonesia (Fig. 3), and had a higher FC as well. Different forest types can likely explain this difference; in Fig. 3 substantial differences are shown for FL, CC, and FC in primary tropical evergreen forest, secondary tropical evergreen forest, and tropical dry forest. Obviously, the number of measurements conducted in a specific forest type will impact the biomeaveraged value found for a certain region. Clearly, the definition of a certain biome is not always straightforward, and uncertainty regarding regional discrepancies within the different biomes should be taken into account when averaged values are interpreted and used by the modeling communities.

Coming back to the question posed in the beginning of this section, we think care should be taken with using biomeaveraged values. They provide a guideline, but the path forward is to continue developing models or remote sensing options that aim to account for variability within biomes, and to use the database accompanying this paper to constrain these models, rather than simply to use biome-averaged values (further discussed in Sect. 3.2). Use of FC for specific vegetation types within broader biomes (like the different crop types as presented in Fig. 6) or fuel categories offers an interesting alternative and is further discussed in Sect. 3.4.

\subsection{Field measurement averages and comparison with GFED3}

Although the definition of a certain biome is not always straightforward, the biome-averaged values that we presented in this paper are still valuable for highlighting differences in fire characteristics between regions with 
specific vegetation and climate characteristics. We compared our work with estimates from the Global Fire Emissions Database version 3 (GFED3) and several FRE derived studies (Sect. 3.3). GFED3 fire emissions estimates (monthly $0.5^{\circ} \times 0.5^{\circ}$ fields) are based on estimates of burned area (Giglio et al., 2010) and the satellite-driven Carnegie-AmesStanford Approach (CASA) biogeochemical model (van der Werf et al., 2010). To calculate FC we divided the GFED3 total biome-specific emissions estimates ( $\mathrm{g}$ dry matter) in every modeling grid cell by the total burned area observed for every grid cell. Since one grid cell may consist of multiple biomes we followed the GFED3 fractionation of emissions estimates, which represents the contribution of a certain biome to total emissions within one grid cell. Biomespecific information on the area burned within one grid cell was not available, and therefore we assumed that burned area followed the same fractionation as the GFED3 emissions estimates. This assumption may overestimate or underestimate biome-averaged GFED3 FC values: for example, in a deforestation grid cell that consists of savannas and tropical evergreen forests, the contribution of savanna fire emissions to total emissions can be small, even when the contribution of savanna burned area to total burned area observed in a grid cell is actually quite large. In this specific case - when assuming that burned area followed the same fractionation as the emissions - the estimated FC of savannas would be overestimated.

In Table 3 an overview is given for biome-specific FL, CC, and FC that we estimated from data found in the literature. In the fifth column FC per unit burned area of GFED3 is shown for the collocated grid cells, i.e., grid cells in which measurements were taken, and the sixth column presents the difference between GFED3 FC and the field measurements. In general, substantial differences were found between colocated GFED3 FC and the field measurements. Although the average FC agreed reasonably well $(<40 \%)$ for crop residue, tropical peat and the boreal peat biome, much larger discrepancies $(>59 \%)$ were found for the other biomes. Many field measurements for these biomes had a standard deviation that was close to the measurement average, indicating that the uncertainty is substantial.

Within the savanna biome GFED3 overestimated the FC by $72 \%$ compared to the measurements, and this overestimation was even higher for grassland regions $(78 \%)$. A possible cause of these discrepancies is that field campaigns tend to focus on frequently burning areas, so fuels do not have the time to build up and increase their FL (van der Werf et al., 2010). Because of the relatively coarse $0.5^{\circ}$ resolution of GFED3, the fire frequency in GFED is the average of more and less frequently burning patches and thus potentially longer than in field sampling sites. On the other hand, only a very small portion of the land's surface burns annually (van der Werf et al., 2013). Improved resolution for the models may help to alleviate this problem and bring model values closer to the field measurements, although it is very unlikely that this is the only reason for the noted discrepancy.

For tropical forests, an important biome due to large-scale deforestation emissions, substantial differences were found as well: GFED 3 overestimated FC by $71 \%$ compared to the field measurement average for collocated grid cells. This discrepancy may be partly explained by the fact that repeated fires in the tropical forest domain (when forest slash that did not burn in a first fire is subject to additional fires during the same dry season) are not always included in the field measurements. Within GFED3, on the other hand, these repeated fires were modeled by the number of active fires observed in the same grid cell (fire persistence), which yields information on the fuel load and type of burning (Morton et al., 2008; van der Werf et al., 2010). Regional differences within the biome, as discussed in Sect. 3.1, will also contribute to the differences found: in our case, the field measurement average was biased towards evergreen tropical forest fires, but when the emphasis is put on fires in secondary or tropical dry forests this average value could change significantly (Fig. 3). It is likely that grid cell heterogeneity in tropical deforestation regions explains the large discrepancy found for the pasture biome, where GFED3 FC overestimated the field measurements by almost $500 \%$. For these specific pasture grid cells, GFED3 may have been biased towards tropical evergreen deforestation fires, thereby increasing the average FC.

In the temperate forest biome $\mathrm{FC}$ was underestimated in GFED 3 by $74 \%$ compared to the field measurement average for collocated grid cells. In our averaged field measurement estimate we included all measurements presented in Table 1c. As noticed in Sect. 2.3, it is likely though that studies that provided a total FC (i.e., the FC of ground, surface and/or crown fuels) are more representative of wildfires. Prescribed burns, on the other hand, tend to burn less fuel and therefore the studies that only include ground or surface fuels were probably more representative for this fire type. When focusing on studies that provide information on one specific fuel class only, the field average for the temperate forest would be significantly lower $\left(13 \pm 12 \mathrm{tha}^{-1}\right)$ as well as the discrepancy with GFED3 $(+14 \%)$. This FC value of $13 \mathrm{tha}^{-1}$ may be more realistic for prescribed fires, which contribute to roughly $50 \%$ of all temperate forest fire emissions in the contiguous United States (CONUS). Still, it remains very uncertain how well FC measured for specific fuel classes is representative for prescribed fires and wildfires. This issue also counts for boreal forests, where GFED3 overestimated the field measurements by almost $80 \%$. When only including studies that provided a total FC (i.e., the FC of ground, surface and/or crown fuels), the field average for the boreal forest would increase from $35 \pm 24$ to $39 \pm 19 \mathrm{tha}^{-1}$ and the discrepancy with GFED3 would decrease (from +79 to $+60 \%$ ). This value of $39 \pm 19 \mathrm{tha}^{-1}$ may be more representative of boreal wildfires. Note that for temperate and boreal forest measurements sometimes the more restrictive definition of FL (as presented in Sect. 1) was used, and this 
Table 3. Biome-averaged values for fuel load (FL), combustion completeness (CC), and fuel consumption (FC) field measurements. Column 5 shows the FC per unit burned area as used in GFED3 (FC $\mathrm{GFED}_{3}$ ) and in column 6 the difference $(\%)$ in $\mathrm{FC}_{\mathrm{GFED} 3}$ compared to the average FC of field measurements is given. Standard deviation (SD) is shown in parentheses.

\begin{tabular}{llllll}
\hline Biome & $\begin{array}{l}\mathrm{FL} \\
\left(\mathrm{tha}^{-1}\right)\end{array}$ & $\begin{array}{l}\mathrm{CC} \\
(\%)\end{array}$ & $\begin{array}{l}\mathrm{FC} \\
\left(\mathrm{tha}^{-1}\right)^{\mathrm{a}}\end{array}$ & $\begin{array}{l}\mathrm{FC}_{\mathrm{GFED}} \\
\left(\mathrm{t} \mathrm{ha}^{-1}\right)^{\mathrm{b}}\end{array}$ & $\begin{array}{l}\text { Difference } \\
(\%)^{\mathrm{c}}\end{array}$ \\
\hline Savanna & $7.6(6.5)$ & $71(26)$ & $4.6(2.2)$ & 7.9 & +72 \\
Grassland savanna & $5.3(2.0)$ & $81(16)$ & $4.3(2.2)$ & 7.7 & +78 \\
Wooded savanna & $11(9.1)$ & $58(32)$ & $5.1(2.2)$ & 8.1 & +59 \\
Tropical forest & $285(137)$ & $49(22)$ & $126(77)$ & 215 & +71 \\
Temperate forest & $115(144)$ & $61(18)$ & $58(72)$ & 15 & -74 \\
Boreal forest & $69(61)$ & $51(17)$ & $35(24)$ & 62 & +79 \\
Pasture & $74(34)$ & $47(27)$ & $28(9.3)$ & 168 & +491 \\
Shifting cultivation & $44(-)$ & $47(-)$ & $23(-)$ & 6.5 & -72 \\
Crop residue & $8.3(9.9)^{\mathrm{d}}$ & $75(21)$ & $6.5(9.0)$ & 5.6 & -13 \\
Chaparral & $35(23)^{\mathrm{e}}$ & $76(6.2)$ & $27(19)$ & 3.5 & -87 \\
Tropical peatland & $1056(876)^{\mathrm{f}}$ & $27(-)$ & $314(196)$ & 228 & -27 \\
Boreal peatland & - & - & $42(-)$ & 25 & -40 \\
Tundra & $165(15)$ & $24(5.0)$ & $40(-)$ & - & - \\
\hline
\end{tabular}

${ }^{a}$ For biomes where only one or two measurements are available, no uncertainty estimate is given.

b FC per unit area burned according to GFED3, averaged over 1997-2009. The number represents the FC rate for the collocated grid cells, i.e., grid cells in which field measurements were taken. Note that for this calculation the assumption was made that GFED burned area is equally divided over different fire types in one grid cell, which may influence average $\mathrm{FC}_{\mathrm{GFED}} 3$ values.

${ }^{\mathrm{c}} \mathrm{FC}_{\mathrm{GFED} 3}$ compared to the average $\mathrm{FC}$ of field measurements for collocated grid cells. Positive numbers indicate that $\mathrm{FC}_{\mathrm{GFED} 3}$ is higher than the average $\mathrm{FC}$ of field measurements.

${ }^{\mathrm{d}}$ We assumed an average CC of $88 \%$ as reported in McCarty et al. (2011) to estimate FL for the study of Lara et al. (2005).

e We assumed a CC of $76 \%$ (average CC for the studies of Hardy et al., 1996 and Yokelson et al., 2013) to estimate FL for the study of Cofer III et al. (1988).

f We assumed an average CC of $27.2 \%$, as reported in Usup et al. (2004), to estimate FL for the studies of Page et al. (2002) and Ballhorn et al. (2009).

$\mathrm{g}$ For the measurement location in the tundra biome no area burned was detected by GFED, and therefore no comparison with GFED3 estimates was made.

can have an impact on FC values as well; if one applies a CC calculated with respect to a restrictive pre-fire FL to the total biomass available, the overall FC that was estimated can be too high.

For most biomes, a few field measurements had an FC that was 1 order of magnitude larger than the other values listed in Table 1, which explains the discrepancy between the median and average FC values that was sometimes found (e.g., the "Australia and Tasmania" region in Fig. 4). By neglecting these "outliers" the biome-averaged values may change significantly, but this could lead to erroneously low or high estimates as well. In general, FC shows large variability between biomes, within biomes, and even within a specific fuel type. FC is often hard to measure, and since only a few measurements are available for some biomes, care should be taken when using the biome-averaged values presented in this paper.

\subsection{Field measurement averages and comparison with FRE derived FC estimates}

Besides a comparison with GFED3 data, we performed a comparison of field measurement averages with fire radiative energy (FRE, time-integrated FRP) derived estimates as well. The basis of the FRE approach for estimating FC is that the heat content of vegetation is more or less constant, and that the FRE released and observed through a sensor can be converted to FC by the use of a constant factor, which was found to be $0.368 \pm 0.015 \mathrm{~kg} \mathrm{MJ}^{-1}$ across of a range of fuels burned under laboratory conditions (Wooster et al., 2005). More recent field experiments, however, indicated that the conversion factor might be slightly lower for grasslands in North America (Kumar et al., 2011; Schroeder et al., 2014). Smith et al. (2013) investigated the relationship between FC and FRE for pine needles with different fuel moisture contents, and found that FRE released per kilogram biomass consumed decreased with fuel moisture content due to the energy required to evaporate and desorb the water contained in the fuel. Thus, corrections for FRE based FC assessments may be needed for fuels that burn at higher fuel moisture contents. Differences in heat content of fuel may introduce additional variation: for example, a clear relationship between FRE and FC has not yet been demonstrated for fires that burn mostly in the smoldering stage, like organic soils in boreal forests or large woody debris and trunks in tropical deforestation regions. Another potential source of uncertainty in the relation between satellite-derived FRE and 
FC is the correction for atmospheric disturbances, which may significantly alter FRP retrievals and hence estimates of FC (Schroeder et al., 2014). Note that, currently, atmospheric correction is not performed for the standard fire products derived from MODIS. Moreover, Schroeder et al. (2014) also indicate that cloud masking in the MODIS FRP product may lead to FRP underestimates as hotspots under thick smoke may erroneously be masked out.

Despite all these uncertainties this approach is promising and there are a number of studies that relate FRE to FC on regional (Roberts et al., 2011; Freeborn et al., 2011) to global scales (Vermote et al., 2009; Ellicott et al., 2009), and Kaiser et al. (2012) used FRE to represent biomass burning in an operational chemical weather forecast framework. However, since such estimates can be derived independently of burned area, only a limited number of studies allow a straightforward comparison to the $\mathrm{FC}$ values given in mass units per area burned from the field experiments used in this study.

A common finding of FRE-based estimates is that FC is generally lower than GFED estimates, as shown by Roberts et al. (2011) who estimated FC for Africa through an integration of MODIS burned area and Meteosat Spinning Enhanced Visible and Infrared Imager (SEVIRI) derived FRP and found values that were about $35 \%$ lower than GFED. For the savanna biome a median FC of $\sim 4 \mathrm{tha}^{-1}$ was found for grassland and shrubland. This corresponds relatively well to the mean of $4.3 \pm 2.2$ and $5.1 \pm 2.2 \mathrm{tha}^{-1}$ found in the grassland savanna and wooded savanna field studies we compiled, respectively. Boschetti and Roy (2009) explored temporal integration and spatial extrapolation strategies for fusing MODIS FRP and MODIS burned area data over a single large fire in a grassland dominated area with sparse eucalypt trees in northern Australia. They estimated an FC range of 3.97-4.13 $\mathrm{tha}^{-1}$, which is well within the range found in the Australian FC studies summarized in Table 1. Kumar et al. (2011) exploited properties of the power law distribution to estimate FC from FRP for an Australian savanna and a study area in the Brazilian Amazon. While their FC estimate of $4.6 \mathrm{tha}^{-1}$ of the Australian site is similar to the temporal integration results of Boschetti and Roy (2009), the estimate for the Brazilian site is above $250 \mathrm{tha}^{-1}$ and thus substantially higher than the biome-averaged value for Brazilian tropical forest $\left(117 \pm 56 \mathrm{tha}^{-1}\right)$.

In general, realistic values are often obtained for wellobserved fires, but unrealistically low or high values can often occur especially for smaller fires due to the sparseness of FRP observations and inaccuracies in the temporal interpolation and the burned area estimates. While FRE seems to provide realistic estimates under a range of conditions, issues of undersampling of FRE and - maybe less importantly - the conversion of FRE to FC still remain to be addressed more completely in order to derive spatially explicit FC estimates using the FRP approach.

\subsection{Fuel consumption for different fuel categories}

As discussed in Sect. 3.1, the interpretation of average FC values for each biome should be done carefully. As an alternative to biome-averaged values, we also provided FC for specific fuel categories, which may be more useful for certain research areas or modeling communities. In Table 2 fuel category information was presented for the savanna, tropical forest, temperate forest and boreal forest biomes. We focused on the main fuel categories found in the literature, and classified these according to the US classification system. Most of these fuel categories were similarly defined in different studies and biomes; the woody debris classes for example were systematically based on their time lag. However, for measurements conducted in boreal forests the definition of woody fuel classes was less consistent, mainly due to differences between Canadian and American sampling methodologies (Keane, 2012). The difference between surface and ground fuels can therefore be especially vague: e.g., litter is classified as surface fuel according to the US fire management standards, while many Canadian studies define litter and organic soils as the forest floor and thus as the ground fuel class. Obviously, this can cause problems when comparing studies, and therefore we recommend a more uniform measurement protocol for this fuel type and biome.

Certain fuel type averages presented in this paper were based on a minimum of three different studies. For these fuel categories specifically, more field measurements are needed to decrease the uncertainty and better understand the variations found, especially within the boreal and tropical forest biomes. Measurements in the boreal and tropical peat biomes deserve specific attention in future measurement campaigns: although peat fires have been studied in several field campaigns, they still remain one of the least understood fire types due to poor knowledge of the depth of the burning and the complex mix of trace gases emitted in these fires as a consequence of the below-ground combustion that is less efficient than during surface or crown fires. Additional studies are needed in order to capture fully the variability and processes occurring in these biomes, especially considering their large FL and FC. Another biome that deserves more attention in future studies is crop residue, since our understanding of FC variability for different crop types is still poor.

\section{Summary}

This study aimed to compile peer-reviewed literature on measured fuel consumption in landscape fires. The field measurements were partitioned into 11 different biomes, and for each biome we have reported biome averages and other statistics. For some biomes, we provided information on different fuel categories as well. The number of study sites varied from 1 for the tundra biome to 39 different measurement sites in the boreal forest biome. In total, we compiled 124 unique 
measurement locations. The biome-averages and fuel-typespecific data of fuel load and fuel consumption can be used to constrain models, or can be used as an input parameter in calculating emissions. Care should be taken though with using biome-averaged values because it is unclear whether these are representative and because there is substantial variability within biomes, as indicated by the large standard deviations found.

Modeled values from GFED3 corresponded reasonably well to the co-located measured values for all biomes except for the savanna and tropical forest, where GFED-derived values were over a factor 2 too high. In tropical forests, part of this discrepancy can be explained because field measurements only take one fire into account, while GFED also accounts for consecutive fires that boost fuel consumption.

Although the overall spatial representativeness of the fuel consumption field measurements was reasonable for most fire-prone regions, several important regions from a fire emissions perspective - including Southeast Asia, eastern Siberia, and central Africa - were severely underrepresented. When new information on fuel consumption becomes available, the field measurement database will be updated. The most up-to-date version can be retrieved from http://www.falw.vu/ gwerf/FC. As a next step, we aim to improve our understanding of the drivers of regional and temporal variability within biomes, as well as for different fuel categories.

Acknowledgements. The workshop that led to this paper was sponsored by the EU FP7 COCOS project. Thijs van Leeuwen, Guido van der Werf, and Rob Detmers acknowledge funding from the EU FP7 MACC-II project (contract number 218793) and the EU FP7 GeoCarbon project (contract number 283080).

Edited by: K. Thonicke

\section{References}

Akagi, S. K., Yokelson, R. J., Wiedinmyer, C., Alvarado, M. J., Reid, J. S., Karl, T., Crounse, J. D., and Wennberg, P. O.: Emission factors for open and domestic biomass burning for use in atmospheric models, Atmos. Chem. Phys, 11, 4039-4072, doi:10.5194/acp-11-4039-2011, 2011.

Amiro, B. D., Todd, J. B., Wotton, B. M., Logan, K. A., Flannigan, M. D., Stocks, B. J., Mason, J. A., Martell, D. L., and Hirsch, K. G.: Direct carbon emissions from Canadian forest fires, 19591999, Can. J. For. Res., 31, 512-525, 2001.

Andreae, M. O. and Merlet, P.: Emission of trace gases and aerosols from biomass burning, Global Biogeochem. Cy., 15, 955-966, 2001

Araújo, T., Carvalho Jr., J., and Higuchi, N.: A tropical rainforest clearing experiment by biomass burning in the state of Pará, Brazil, Atmos. Environ., 33, 1991-1998, 1999.
Archibald, S., Scholes, R. J., Roy, D. P., Roberts, G., and Boschetti, L.: Southern African fire regimes as revealed by remote sensing, Int. J. Wildland Fire, 19, 861-878, 2010.

Baccini, A., Goetz, S. J., Walker, W. S., Laporte, N. T., Sun, M., Sulla-Menashe, D., Hackler, J., Beck, P. S. A., Dubuyah, R., Friedl, M. A., Samanta, S., and Houghton, R. A.: Estimated carbon dioxide emissions from tropical deforestation improved by carbon-density maps, Nat. Clim. Change, 2, 182-185, 2012.

Balch, J. K., Nepstad, D. C., Brando, P. M., Curran, L. M., Portela, O., de Carvalho Jr., O., and Lefebvre, P.: Negative fire feedback in a transitional forest of southeastern Amazonia, Global. Change Biol., 14, 2276-2287, 2008.

Ballhorn, U., Siegert, F., Mason, M., and Limin, S.: Derivation of burn scar depths and estimation of carbon emissions with LIDAR in Indonesian peatlands, Proc. Natl. Acad. Sci., 106, 2121321218, 2009.

Barbosa, R. and Fearnside, P.: Pasture burning in Amazonia: Dynamics of residual biomass and the storage and release of aboveground carbon, J. Geophys. Res.-Atmos., 101, 25847-25857, 1996.

Barbosa, R. I. and Fearnside, P. M.: Above-ground biomass and the fate of carbon after burning in the savannas of Roraima, Brazilian Amazonia, Forest Ecol. Manag., 216, 295-316, 2005.

Benscoter, B. W. and Wieder, R. K.: Variability in organic matter lost by combustion in a boreal bog during the 2001 Chisholm fire, Can. J. For. Res., 33, 2509-2513, 2003.

Bêche, L. A., Stephens, S. L., and Resh, V. H.: Effects of prescribed fire on a Sierra Nevada (California, USA) stream and its riparian zone, Forest Ecol. Manag., 218, 37-59, 2005.

Bilbao, B. and Medina, E.: Types of grassland fires and nitrogen volatilization in tropical savannas of Venezuela, in: Biomass burning and global change, vol 2. Biomass burning in South America, Southeast Asia and temperate and boreal ecosystems, and the oild fires of Kuwait, edited by: Levine, J. S., Cambridge, MIT press, 569-574, 1996.

Boby, L. A., Schuur, E. A., Mack, M. C., Verbyla, D., and Johnstone, J. F.: Quantifying fire severity, carbon, and nitrogen emissions in Alaska's boreal forest, Ecol. Appl., 20, 1633-1647, 2010.

Boschetti, L. and Roy, D. P.: Strategies for the fusion of satellite fire radiative power with burned area data for fire radiative energy derivation, J. Geophys. Res., 114, D20302, doi:10.1029/2008JD011645, 2009.

Bowman, D. M. J. S., Balch, J. K., Artaxo, P., Bond, W. J., Carlson, J. M., Cochrane, M. A., D’Antonio, C. M., DeFries, R. S., Doyle, J. C., Harrison, S. P., Johnston, F. H., Keeley, J. E., Krawchuk, M. A., Kull, C. A., Marston, J. B., Moritz, M. A., Prentice, I. C., Roos, C. I., Scott, A. C., Swetnam, T. W., van der Werf, G. R., and Pyne, S. J.: Fire in the Earth System, Science, 324, 481-484, 2009.

Bradshaw, L. S., Deeming, J. E., Burgan, R. E., and Cohen, J. D.: The 1978 National Fire-Danger Rating System: Technical documentation. USDA Forest Service, Intermountain Forest and Range Experiment Station General Technical Report INT-169, 1983.

Brandt, J. P.: The extent of the North American boreal zone, Environ. Rev., 17, 101-161, 2009.

Brown, J. K.: A Planar Intersect Method for Sampling Fuel Volume and Surface Area, Forest Science, 1971. 
Campbell, J., Donato, D., Azuma, D., and Law, B.: Pyrogenic carbon emission from a large wildfire in Oregon, United States, J. Geophys. Res.-Biogeosci., 112, G04014, doi:10.1029/2007JG000451, 2007.

Cardille, J. A. and Foley, J. A.: Agriculture Land-use Change in Brazilian Amazonia between 1980 and 1995: Evidence from Integrated Satellite and Census Data, Remote Sens. Environ., 87, 551-562, 2003.

Carter, M. C. and Darwin Foster, C.: Prescribed burning and productivity in southern pine forests: a review, Forest Ecol. Manag., 191, 93-109, 2004.

Carvalho, J. A., Santos, J. M., Santos, J. C., Leitão, M. M., and Higuchi, N.: A tropical rainforest clearing experiment by biomass burning in the Manaus region, Atmos. Environ., 29, 2301-2309, 1995.

Carvalho Jr., J. A., Higuchi, N., Araújo, T. M., and Santos, J. C.: Combustion completeness in a rainforest clearing experiment in Manaus, Brazil, J. Geophys. Res., 103, 13195-13199, 1998.

Carvalho Jr., J. A., Costa, F. S., Veras, C. A. G., Sandberg, D. V., Alvarado, E. C., Gielow, R., Serra Jr., A. M., and Santos, J. C.: Biomass fire consumption and carbon release rates of rainforestclearing experiments conducted in northern Mato Grosso, Brazil, J. Geophys. Res., 106, 17877-17887, 2001.

Carvalho Jr., J. A., Veras, C. A. G., Soares Neto, T. G., Costa, M. A. M., Costa, F. S., van Leeuwen, T. T., Krieger Filho, G. C., Tourigny, E., Forti, M. C., Fostier, A. H., Siqueira, M. B., Santos, J. C., Anselmo, E., Santos, C. R., Lima, B. A., Cascão, P., and Frade Jr., E. F.: Biomass Consumption and $\mathrm{CO}_{2}$ and $\mathrm{CO}$ emission amounts in a Forest Clearing Fire in Western Amazonia. Scientific Report, Thematic Project, Project 2008/04490-4, FAPESP (Fundação de Amparo à Pesquisa do Estado de São Paulo), 2011.

Chen, Y., Randerson, J. T., Morton, D. C., DeFries, R. S., Collatz, G. J., Kasibhatla, P. S., Giglio, L., Jin, Y., and Marlier, M. E.: Forecasting Fire Season Severity in South America Using Sea Surface Temperature Anomalies, Science, 334, 787-791, 2011.

Cheney, P. and Sullivan, A.: Grassfires. Fuel, Weather and Fire Behaviour, CSIRO Publishing, Melbourne, 1997.

Christian, T. J., Yokelson, R. J., Carvalho, J. A. J., Griffith, D. W. T., Alvarado, E. C., Santos, J. C., Neto, T. G. S., Gurgel Veras, C. A., and Hao, W. M.: The tropical forest and fire emissions experiment: Trace gases emitted by smoldering logs and dung from deforestation and pasture fires in Brazil, J. Geophys. Res.Atmos., 112, D18308, doi:10.1029/2006JD008147, 2007.

Cofer III, W. R., Levine, J. S., Riggan, P. J., Sebacher, D. I., Winstead, E. L., Shaw Jr., E. F., Brass, J. A., and Ambrosia, V. G.: Trace gas emissions from a Mid-latitude prescribed chaparral fire, J. Geophys. Res., 93, 1653-1658, 1988.

Cook, G. D.: The fate of nutrients during fires in a tropical savanna, Austral. Ecol., 19, 359-365, 1994.

Cooke, W. F. and Wilson, J. J. N.: A global black carbon aerosol model, J. Geophys. Res., 101, 19395, doi:10.1029/96JD00671, 1996.

Crutzen, P. J. and Andreae, M. O.: Biomass Burning in the Tropics Impact on Atmospheric Chemistry and Biogeochemical Cycles, Science, 250, 1669-1678, 1990.

De Castro, E. A. and Kauffman, J. B.: Ecosystem structure in the Brazilian Cerrado: a vegetation gradient of aboveground biomass, root mass and consumption by fire, J. Trop. Ecol., 14, 263-283, 1998. de Groot, W. J., Landry, R., Kurz, W. A., Anderson, K. R., Englefield, P., Fraser, R. H., Hall, R. J., Banfield, E., Raymond, D. A., Decker, V., Lynham, T. J., and Pritchard, J. M.: Estimating direct carbon emissions from Canadian wildland fires, Int. J. Wildland Fire, 16, 593, doi:10.1071/WF06150, 2007.

de Groot, W. J., Pritchard, J. M., and Lynham, T. J.: Forest floor fuel consumption and carbon emissions in Canadian boreal forest fires, Can. J. For. Res., 39, 367-382, 2009.

de Groot, W. J., Cantin, A. S., Flannigan, M. D., and Soja, A. J.: A comparison of Canadian and Russian boreal forest fire regimes, Forest Ecol. Manag., 294, 23-34, 2013 a.

de Groot, W. J., Flannigan, M. D., and Cantin, A. S.: Climate change impacts on future boreal fire regimes, Forest Ecol. Manag., 294, 35-44, 2013b.

Dennis, A., Fraser, M., Anderson, S., and Allen, D.: Air pollutant emissions associated with forest, grassland, and agricultural burning in Texas, Atmos. Environ., 36, 3779-3792, 2002.

Eck, T. F., Holben, B. N., Reid, J. S., Mukelabai, M. M., Piketh, S. J., Torres, O., Jethva, H. T., Hyer, E. J., Ward, D. E., Dubovik, O., Sinyuk, A., Schafer, J. S., Giles, D. M., Sorokin, M., Smirnov, A., and Slutsker, I.: A seasonal trend of single scattering albedo in southern African biomass-burning particles: Implications for satellite products and estimates of emissions for the world's largest biomass-burning source, J. Geophys. Res.-Atmos., 118, 6414-6432, 2013.

Ellicott, E., Vermote, E., Giglio, L., and Roberts, G.: Estimating biomass consumed from fire using MODIS FRE, Geophys. Res. Lett, 36, L13401, doi:10.1029/2009GL038581, 2009.

Fearnside, P. M.: Greenhouse gas emissions from deforestation in the Brazilian Amazon, in: Carbon emissions and sequestration in forests: case studies from seven developing countries, (Draft edition) US Environmental Protection Agency, Climate Change Division, edited by: Makundi, W. and Sathaye, J., Washington DC and Energy and Environment Division, Lawrence Berkeley Laboratory, Berkeley, CA, 1-73, 1992.

Fearnside, P. M., Leal Jr., N., and Moreira Fernandes, F.: Rainforest burning and the global carbon budget: biomass, combustion efficiency, and charcoal formation in the Brazilian Amazon, J. Geophys. Res., 98, 16733-16743, 1993.

Fearnside, P. M., de Alencastro Graça, P. M. L., Leal Jr., N., Rodrigues, F., and Robinson, J. M.: Tropical forest burning in Brazilian Amazonia: measurement of biomass loading, burning efficiency and charcoal formation at altamira, Pará, Forest Ecol. Manag., 123, 65-79, 1999.

Fearnside, P. M., de Alencastro Graça, P., and Rodrigues, F.: Burning of Amazonian rainforests: burning efficiency and charcoal formation in forest cleared for cattle pasture near Manaus, Brazil, Forest Ecol. Manag., 146, 115-128, 2001.

Field, R., van der Werf, G., and Shen, S.: Human amplification of drought-induced biomass burning in Indonesia since 1960, Nat. Geosci., 2009.

FIRESCAN Science Team: Fire in Ecosystems of Boreal Eurasia: The Bor Forest Island Fire Experiment Fire Research Campaign Asia-North (FIRESCAN), in: Biomass Burning and Global Change, edited by: Levine, J. S., MIT Press, Cambridge, Mass., 848-873, 1996.

Flannigan, M., Cantin, A. S., de Groot, W. J., Wotton, M., Newbery, A., and Gowman, L. M.: Global wildland fire season severity in the 21st century, Forest Ecol. Manag., 294, 54-61, 2013. 
Freeborn, P. H., Wooster, M. J., and Roberts, G.: Addressing the spatiotemporal sampling design of MODIS to provide estimates of the fire radiative energy emitted from Africa, Remote Sens. Environ., 115, 475-489, 2011.

French, N. H. F., Goovaerts, P., and Kasischke, E. S.: Uncertainty in estimating carbon emissions from boreal forest fires, J. Geophys. Res.-Atmos., 109, D14S08, doi:10.1029/2003JD003635, 2004

French, N. H. F., McKenzie, D., Hamermesh, N., and McCarty, J.: NACP Integrated Wildland and Cropland $30 \mathrm{~m}$ Fuel Characteristics Map, USA, 2010.

Frost, P. G. H.: The ecology of miombo woodlands, in: The Miombo in Transition: Woodlands and Welfare in Africa, edited by: Campbell, B., 11-58, CIFOR, Bogor, Indonesia, 1996.

Giglio, L., Loboda, T., Roy, D. P., Quayle, B., and Justice, C. O.: An active-fire based burned area mapping algorithm for the MODIS sensor, Remote Sens. Environ., 113, 408-420, 2009.

Giglio, L., Randerson, J. T., van der Werf, G. R., Kasibhatla, P. S., Collatz, G. J., Morton, D. C., and DeFries, R. S.: Assessing variability and long-term trends in burned area by merging multiple satellite fire products, Biogeosciences, 7, 1171-1186, doi:10.5194/bg-7-1171-2010, 2010.

Gignoux, J., Mordelet, P., and Menaut, J. C.: Biomass cycle and primary production, Lamto: Structure, functioning and dynamics of a savanna ecosystem, edited by: Abbadie, L., Gignoux, J., LeRoux, X., and Lepage, M., 115-137, 2006.

Gill, A. M. and Allan, G.: Large fires, fire effects and the fire-regime concept, Int. J. Wildland Fire, 17, 688, doi:10.1071/WF07145, 2008.

Goode, J. G., Yokelson, R. J., Ward, D. E., Susott, R. A., Babbitt, R. E., Davies, M. A., and Hao, W. M.: Measurements of excess $\mathrm{O}_{3}, \mathrm{CO}_{2}, \mathrm{CO}, \mathrm{CH}_{4}, \mathrm{C}_{2} \mathrm{H}_{4}, \mathrm{C}_{2} \mathrm{H}_{2}, \mathrm{HCN}, \mathrm{NO}, \mathrm{NH}_{3}$, $\mathrm{HCOOH}, \mathrm{CH}_{3} \mathrm{COOH}, \mathrm{HCHO}$, and $\mathrm{CH}_{3} \mathrm{OH}$ in 1997 Alaskan biomass burning plumes by airborne Fourier transform infrared spectroscopy (AFTIR), J. Geophys. Res., 105, 22147-22166, 2000.

Goodrick, S. L., Shea, D., and Blake, J.: Estimating fuel consumption for the upper coastal plain of South Carolina, South, J. Appl. For., 34, 5-12, 2010.

Guild, L. S., Kauffman, J. B., Ellingson, L. J., Cummings, D. L., Castro, E. A., Babbitt, R. E., and Ward, D. E.: Dynamics associated with total aboveground biomass, $\mathrm{C}$, nutrient pools, and biomass burning of primary forest and pasture in Rondônia, Brazil during SCAR-B, J. Geophys. Res.-Atmos., 103, 3209132100, 1998.

Harden, J. W., Trumbore, S. E., Stocks, B. J., Hirsch, A., Gower, S. T., O'Neill, K. P., and Kasischke, E. S.: The role of fire in the boreal carbon budget, Glob. Change Biol., 6, 174-184, 2000.

Harden, J. W., Neff, J. C., Sandberg, D. V., Turetsky, M. R., Ottmar, R., Gleixner, G., Fries, T. L., and Manies, K. L.: Chemistry of burning the forest floor during the FROSTFIRE experimental burn, interior Alaska, 1999, Global Biogeochem. Cy., 18, GB3014, doi:10.1029/2003GB002194, 2004.

Harden, J. W., Manies, K. L., Turetsky, M. R., and Neff, J. C.: Effects of wildfire and permafrost on soil organic matter and soil climate in interior Alaska, Glob. Change Biol., 12, 2391-2403, 2006.

Hardy, C. C., Conard, S. G., Regelbrugge, J. C., and Teesdale, D. R.: Smoke emissions from prescribed burning of southern Cali- fornia chaparral, United States Department of Agriculture, Forest Service Research Paper PNW-RP-486, 1996.

Hély, C., Dowty, P. R., Alleaume, S., Caylor, K. K., Korontzi, S., Swap, R. J., Shugart, H. H., and Justice, C. O.: Regional fuel load for two climatically contrasting years in southern Africa, J. Geophys. Res., 108, D13, doi:10.1029/2002JD002341, 2003 a.

Hély, C., Alleaume, S., Swap, R. J., Shugart, H. H., and Justice, C. O.: SAFARI-2000 characterization of fuels, fire behavior, combustion completeness, and emissions from experimental burns in infertile grass savannas in western Zambia, J. Ar. Environ., 54, 381-394, 2003b.

Hély, C., Caylor, K. K., Dowty, P., Alleaume, S., Swap, R. J., Shugart, H. H., and Justice, C. O.: A Temporally Explicit Production Efficiency Model for Fuel Load Allocation in Southern Africa, Ecosystems, 10, 1116-1132, 2007.

Higuera, P. E., Chipman, M. L., Barnes, J. L., Urban, M. A., and $\mathrm{Hu}, \mathrm{F}$. S.: Variability of tundra fire regimes in Arctic Alaska: millennial-scale patterns and ecological implications, Ecol. Appl., 21, 3211-3226, 2011.

Hille, M. G. and Stephens, S. L.: Mixed conifer forest duff consumption during prescribed fires: tree crown impacts, Forest Science, 51, 417-424, 2005.

Hoffa, E. A., Ward, D. E., Hao, W. M., Susott, R. A., and Wakimoto, R. H.: Seasonality of carbon emissions from biomass burning in a Zambian savanna, J. Geophys. Res.-Atmos., 104, 13841-13853, 1999.

Hollis, J. J., Matthews, S., Ottmar, R. D., Prichard, S. J., Slijepcevic, A., Burrows, N. D., Ward, B., Tolhurst, K. G., Anderson, W. R., and Gould, J. S.: Testing woody fuel consumption models for application in Australian southern eucalypt forest fires, Forest Ecol. Manag., 260, 948-964, 2010.

Hu, F. S., Higuera, P. E., Walsh, J. E., Chapman, W. L., Duffy, P. A., Brubaker, L. B., and Chipman, M. L.: Tundra burning in Alaska: linkages to climatic change and sea ice retreat, J. Geophys. Res. Biogeosci., 115, G04002, doi:10.1029/2009JG001270, 2010.

Hughes, R. F., Kauffman, J. B., and Cummings, D. L.: Fire in the Brazilian Amazon, Oecologia, 124, 574-588, 2000a.

Hughes, R. and Kauffman, J.: Ecosystem-scale impacts of deforestation and land use in a humid tropical region of Mexico, Ecological Applications, 2000b.

Hurst, D. F., Griffith, D. W. T., Carras, J. N., Williams, D. J., and Fraser, P. J.: Measurements of trace gases emitted by Australian savanna fires during the 1990 dry season, J. Atmos. Chem., 18, 33-56, 1994.

Hyde, J. C., Smith, A. M. S., Ottmar, R. D., Alvarado, E. C., and Morgan, P.: The combustion of sound and rotten woody debris: a review, Int. J. Wildland Fire, 20, 163-174, 2011.

Ivanova, G. A., Conard, S. G., Kukavskaya, E. A., and McRae, D. J.: Fire impact on carbon storage in light conifer forests of the Lower Angara region, Siberia, Environ. Res. Lett., 6, 045203, doi:10.1088/1748-9326/6/4/045203, 2011.

Jenkins, B. M., Turn, S. Q., and Williams, R. B.: Atmospheric emissions from agricultural burning in California: determination of burn fractions, distribution factors, and crop-specific contributions, Agriculture, Ecosyst. Environ., 38, 313-330, 1992.

Jin, Y., Randerson, J. T., Faivre, N., Capps, S., Hall, A., and Goulden, M. L.: Contrasting controls on wildland fires in Southern California during periods with and without Santa Ana winds, J. Geophys. Res.-Biogeosci., 119, 432-450, 2014. 
Johnston, F. H., Henderson, S. B., Chen, Y., Randerson, J. T., Marlier, M., DeFries, R. S., Kinney, P., Bowman, D. M. J. S., and Brauer, M.: Estimated Global Mortality Attributable to Smoke from Landscape Fires, Environ. Health Perspect., 120, 695-701, 2012.

Johnston, W. J. and Golob, C. T.: Quantifying post-harvest emissions from bluegrass seed production field burning. Department of Crop and Soil Sciences, Washington State University, Washington, DC, Final report, 2004.

Jones, B. M., Kolden, C. A., Jandt, R., Abatzoglou, J. T., Urban, F., and Arp, C. D.: Fire Behavior, Weather, and Burn Severity of the 2007 Anaktuvuk River Tundra Fire, North Slope, Alaska, Arctic, Ant. Alpine Res., 41, 309-316, 2009.

Kaiser, J. W., Heil, A., Andreae, M. O., Benedetti, A., Chubarova, N., Jones, L., Morcrette, J.-J., Razinger, M., Schultz, M. G., Suttie, M., and van der Werf, G. R.: Biomass burning emissions estimated with a global fire assimilation system based on observed fire radiative power, Biogeosciences, 9, 527-554, doi:10.5194/bg-9-527-2012, 2012.

Kane, E. S., Kasischke, E. S., Valentine, D. W., Turetsky, M. R., and McGuire, A. D.: Topographic influences on wildfire consumption of soil organic carbon in interior Alaska: Implications for black carbon accumulation, J. Geophys. Res., 112, G03017, doi:10.1029/2007JG000458, 2007.

Kasischke, E. S., Stocks, B. J., O'Neill, K., French, N. H. F., and Bourgeau-Chavez, L. L.: Direct Effects of Fire on the Boreal Forest Carbon Budget, in: Biomass Burning and Its InterRelationships with the Climate System, edited by: Innes, J. L., Beniston, M., and Verstraete, M. M., Springer Netherlands, Dordrecht, 3, 51-68, 2000.

Kasischke, E. S., Williams, D., and Barry, D.: International Journal of Wildland Fire, Int. J. Wildland Fire, 11, 131, doi:10.1071/WF02023, 2002.

Kasischke, E. S. and Turetsky, M. R.: Kasischke: Recent changes in the fire regime across the North American boreal region-Spatial and temporal patterns of burning across Canada and Alaska, Geophys. Res. Lett., 33, L09703, 2006.

Kasischke, E. S., Loboda, T., Giglio, L., French, N. H. F., Hoy, E. E., de Jong, B., and Riano, D.: Quantifying burned area for North American forests: Implications for direct reduction of carbon stocks, J. Geophys. Res., 116, G04003, doi:10.1029/2011JG001707, 2011.

Kauffman, J. B., Sanford Jr., R. L., Cummings, D. L., Salcedo, I. H., and Sampaio, E. V. S. B.: Biomass and nutrient dynamics associated with slash fires in neotropical dry forests, Ecology, 74, 140-151, 1993.

Kauffman, J. B., Cummings, D. L., Ward, D. E., and Babbitt, R.: Fire in the Brazilian Amazon: 1. Biomass, nutrient pools, and losses in slashed primary forests, Oecologia, 104, 397-408, 1995.

Kauffman, J. B., Cummings, D. L., and Ward, D. E.: Fire in the Brazilian Amazon: 2. Biomass, nutrient pools and losses in cattle pastures, Oecologia, 113, 415-427, 1998.

Kauffman, J. B., Steele, M. D., Cummings, D. L., and Jaramillo, V. J.: Biomass dynamics associated with deforestation, fire, and, conversion to cattle pasture in a Mexican tropical dry forest, Forest Ecol. Manag., 176, 1-12, 2003.
Keane, R. E.: Describing wildland surface fuel loading for fire management: a review of approaches, methods, and systems, Int. J. Wildland Fire, 22, 51-62, 2012.

Keeley, J. E., Safford, H., Fotheringham, C. J., Franklin, J., and Moritz, M.: The 2007 Southern California Wildfires: Lessons in Complexity, J. Forest., 107, 287-296, 2009.

Kloster, S., Mahowald, N. M., Randerson, J. T., Thornton, P. E., Hoffman, F. M., Levis, S., Lawrence, P. J., Feddema, J. J., Oleson, K. W., and Lawrence, D. M.: Fire dynamics during the 20th century simulated by the Community Land Model, Biogeosciences, 7, 1877-1902, doi:10.5194/bg-7-1877-2010, 2010.

Kumar, S. S., Roy, D. P., Boschetti, L., and Kremens, R.: Exploiting the power law distribution properties of satellite fire radiative power retrievals: A method to estimate fire radiative energy and biomass burned from sparse satellite observations, J. Geophys. Res., 116, D19303, doi:10.1029/2011JD015676, 2011.

Lara, L., Artaxo, P., Martinelli, L., Camargo, P., Victoria, R., and Ferraz, E.: Properties of aerosols from sugar-cane burning emissions in Southeastern Brazil, Atmos. Environ., 39, 4627-4637, 2005.

Mack, M. C., Bret-Harte, M. S., Hollingsworth, T. N., Jandt, R. R., Schuur, E. A. G., Shaver, G. R., and Verbyla, D. L.: Carbon loss from an unprecedented Arctic tundra wildfire, Nature, 475, 489492, 2011.

Marengo, J. A., Borma, L. S., Rodriguez, D. A., Pinho, P., Soares, W. R., and Alves, L. M.: Recent Extremes of Drought and Flooding in Amazonia: Vulnerabilities and Human Adaptation, Am. J. Clim. Change, 2, 87-96, 2013.

Maurìcio Lima de Alencastro Graça, P., Fearnside, P. M., and Cerri, C. C.: Burning of Amazonian forest in Ariquemes, Rondônia, Brazil: biomass, charcoal formation and burning efficiency, Forest Ecol. Manag., 120, 179-191, 1999.

Maxwell, W. G. and Ward, F. R.: Photo series for quantifying forest residues in the: ponderosa pine type/ponderosa pine and associated species type/lodgepole pine type, USDA For Ser Gen Tech Rep PNW Pac Northwest For Range Exp Stn US Dep Agric, 1976.

McCarty, J. L.: Remote Sensing-Based Estimates of Annual and Seasonal Emissions from Crop Residue Burning in the Contiguous United States, J. Air Waste Manag. Assoc., 61, 22-34, 2011.

McCarty, J. L., Ellicott, E. A., Romanenkov, V., Rukhovitch, D., and Koroleva, P.: Multi-year black carbon emissions from cropland burning in the Russian Federation, Atmos. Environ., 63, 223268, 2012

Menaut, J. C., Abbadie, L., Lavenu, F., Loudjani, P., and Podaire, A.: Biomass burning in West African savannas, in: Global Biomass Burning - Atmospheric, Climatic, and Biospheric Implications, edited by: Levine, J. S., Massachusetts Institute of Technology Press, Cambridge, MA, USA, 133-142, 1991.

Menaut J. C., Lepage M., and Abbadie, L.: Savannas, woodlands and dry forests in Africa, in: Seasonally Dry Tropical Forests, edited by: Bullock, S. H., Mooney, H. A., and Medina, E. E., Cambridge, UK, Cambridge University Press, 64-92, 1995.

Meyer, C. P., Cook, G. D., Reisen, F., Smith, T. E. L., Tattaris, M., Russell-Smith, J., Maier, S. W., Yates, C. P., and Wooster, M. J.: Direct measurements of the seasonality of emission factors from savanna fires in northern Australia, J. Geophys. Res., 117, D20305, doi:10.1029/2012JD017671, 2012. 
Miranda, H. S., Rocha e Silva, E. P., and Miranda, A. C.: Comportamento do fogo em queimadas de campo sujo, in: Impactos de Queimadas em Areas de Cerrado e Restinga, edited by: Miranda, H. S., Saito, C. H., and Dias, B. F. S., Universidade de Brasilia, Brasilia, DF, Brazil, 1-10, 1996.

Mollicone, D., Eva, H. D., and Achard, F.: Human role in Russian wild fires, Nature, 440, 436-437, 2006.

Moritz, M. A., Moody, T. J., Krawchuk, M. A., Hughes, M., and Hall, A.: Spatial variation in extreme winds predicts large wildfire locations in chaparral ecosystems, Geophys. Res. Lett., 37, L04801, doi:10.1029/2009GL041735, 2010.

Morton, D. C., DeFries, R. S., Randerson, J. T., Giglio, L., Schroeder, W. and Van Der Werf, G. R.: Agricultural intensification increases deforestation fire activity in Amazonia, Glob. Change Biol., 14, 2262-2275, doi:10.1111/j.13652486.2008.01652.x, 2008.

Nash, C. H. and Johnson, E. A.: Synoptic climatology of lightningcaused forest fires in subalpine and boreal forests, Can. J. For. Res., 26, 1859-1874, 1996.

Nepstad, D. C., Verssimo, A., Alencar, A., Nobre, C., Lima, E., Lefebvre, P., Schlesinger, P., Potter, C., Moutinho, P., Mendoza, E., Cochrane, M., and Brooks, V.: Large-scale impoverishment of Amazonian forests by logging and fire, Nature, 398, 505-508, 1999.

Ortiz de Zárate, I., Ezcurra, A., Lacaux, J. P., Van Dinh, P., and Díaz de Argandoña, J.: Pollution by cereal waste burning in Spain, Atmos. Res., 73, 161-170, 2005.

Ottmar, R. D. and Sandberg, D.V.: Predicting Forest Floor Consumption From Wildland Fire in Boreal forests of Alaska, Am. Geophys. Un., 41, 1469, 218-224, 2010.

Page, S. E., Banks, C., and Rieley, J. O.: Tropical peatlands: distribution, extent and carbon storage-uncertainties and knowledge gaps, Peatlands International, 26-27, 2007.

Page, S., Siegert, F., Rieley, J., and Boehm, H.: The amount of carbon released from peat and forest fires in Indonesia during 1997, Nature, 420, 61-65, 2002.

Pivello, V. R.: The Use of Fire in the Cerrado and Amazonian Rainforests of Brazil: Past and Present, Fire Ecol., 7, 24-39, 2011.

Prasad, V. K., Gupta, P. K., Sharma, C., Sarkar, A. K., Kant, Y., Badarinath, K. V. S., Rajagopal, T., and Mitra, A. P.: $\mathrm{NO}_{\mathrm{x}}$ emissions from biomass burning of shifting cultivation areas from tropical deciduous forests of India - estimates from groundbased measurements, Atmos. Environ., 34, 3271-3280, 2000.

Prasad, V. K., Kant, Y., Gupta, P. K., Sharma, C., Mitra, A. P., and Badarinath, K. V. S.: Biomass and combustion characteristics of secondary mixed deciduous forests in Eastern Ghats of India, Atmos. Environ., 35, 3085-3095, 2001.

Randerson, J. T., Chen, Y., Van Der Werf, G. R., Rogers, B. M., and Morton, D. C.: Global burned area and biomass burning emissions from small fires, J. Geophys. Res., 117, G04012, doi:10.1029/2012JG002128, 2012.

Ratnam, J., Bond, W. J., Fensham, R. J., Hoffmann, W. A., Archibald, S., Lehmann, C. E. R., Anderson, M. T., Higgins, S. I., and Sankaran, M.: When is a "forest" a savanna, and why does it matter?, Glob. Ecol. Biogeogr., 20, 653-660, 2011.

Raynolds, M. A., Walker, D. A., and Maier, H. A.: Alaska Arctic Tundra Vegetation Map. Scale 1:4000000, Conservation of Arctic Flora and Fauna (CAFF) Map No. 2, U.S. Fish and
Wildlife Service, Anchorage, Alaska, http://www.arcticatlas.org/ maps/themes/ak/index, 2006.

Rieley, J. O., Ahmad-Shah, A. A., and Brady, M. A.: Tropical Lowland Peatlands of Southeast Asia, edited by: Maltby, E., Immirzi, C. P., and Safford, R. J., IUCN, Gland, Switzerland, 17-53, 1996.

Rieley, J. O., Wüst, R., Jauhiainen, J., Page, S. E., Wösten, H., Hooijer, A., Siegert, F., Limin, S. H., Vasander, H., and Stahlhut, M.: Tropical peatlands: carbon stores, carbon gas Emissions and contribution to climate change Processes, edited by: Maria Strack, Peatlands and Climate Change, 2008.

Righi, C. A., de Alencastro Graça, P. M. L., Cerri, C. C., Feigl, B. J., and Fearnside, P. M.: Biomass burning in Brazil's Amazonian "arc of deforestation": Burning efficiency and charcoal formation in a fire after mechanized clearing at Feliz Natal, Mato Grosso, Forest Ecol. Manag., 258, 2535-2546, 2009.

Roberts, G., Wooster, M. J., Freeborn, P. H., and Xu, W.: Integration of geostationary FRP and polar-orbiter burned area datasets for an enhanced biomass burning inventory, Remote Sens. Environ., 115, 2047-2061, 2011.

Rossiter, N. A., Setterfield, S. A., Douglas, M. M., and Hutley, L. B.: Testing the grass-fire cycle: alien grass invasion in the tropical savannas of northern Australia, Div. Distribut., 9, 169-176, 2003.

Rossiter-Rachor, N. A., Setterfield, S. A., Douglas, M. M., Hutley, L. B., and Cook, G. D.: Andropogon gayanus (Gamba Grass) Invasion Increases Fire-mediated Nitrogen Losses in the Tropical Savannas of Northern Australia, Ecosystems, 11, 77-88, 2007.

Rossiter-Rachor, N. A., Setterfield, S. A., Douglas, M. M., Hutley, L. B., Cook, G. D., and Schmidt, S.: Invasive Andropogon gayanus (Gamba Grass) is an ecosystem transformer of nitrogen relations in Australia's tropical savanna, Ecol. Appl., 19, 15461560, 2009.

Roy, D. P., Jin, Y., Lewis, P. E., and Justice, C. O.: Prototyping a global algorithm for systematic fire-affected area mapping using MODIS time series data, Remote Sens. Environ., 97, 137-162, 2005.

Russell-Smith, J., Yates, C. P., Whitehead, P. J., Smith, R., Craig, R., Allan, G. E., Thackway, R., Frakes, I., Cridland, S., Meyer, M. C. P., and Gill, A. M.: Bushfires "down under": patterns and implications of contemporary Australian landscape burning, Int J. Wildland Fire, 16, 361-377, 2007.

Russell-Smith, J., Murphy, B. P., Meyer, C. P. M., Cook, G. D., Maier, S., Edwards, A. C., Schatz, J., and Brocklehurst, P.: Improving estimates of savanna burning emissions for greenhouse accounting in northern Australia: limitations, challenges, applications, Int. J. Wildland Fire, 18, 1-18, 2009.

Sah, J. P., Ross, M. S., Snyder, J. R., Koptur, S., and Cooley, H. C.: Fuel loads, fire regimes, and post-fire fuel dynamics in Florida Keys pine forests, Int. J. Wildland Fire, 15, 463, doi:10.1071/WF05100, 2006.

Saharjo, B. H. and Nurhayati, A. D.: Domination and composition structure change at hemic peat natural regeneration following burning; a case study in Pelalawan, Riau Province, Biodiversitas, 7, 154-158, 2006.

Sandberg, D. V., Ottmar, R. D., and Cushon, G. H.: International Journal of Wildland Fire, Int. J. Wildland Fire, 10, 381-387, 2001.

Savadogo, P., Zida, D., Sawadogo, L., Tiveau, D., Tigabu, M. and Odén, P. C.: Fuel and fire characteristics in savanna-woodland of 
West Africa in relation to grazing and dominant grass type, Int. J. Wildland Fire, 16, 531, doi:10.1071/WF07011, 2007.

Scholes, R. J., Archibald, S., and von Malitz, G.: Emissions from fire in Sub-Saharan Africa: the magnitude of sources, their variability and uncertainty, Global Environ. Res., 15, 53-63, 2011.

Schroeder, W., Ellicott, E., Ichoku, C., Ellison, L., Dickinson, M. B., Ottmar, R. D., Clements, C., Hall, D., Ambrosia, V., and Kremens, R.: Integrated active fire retrievals and biomass burning emissions using complementary near-coincident ground, airborne and spaceborne sensor data, Remote Sens. Environ., 140, 719-730, 2014.

Seiler, W. and Crutzen, P.: Estimates of gross and net fluxes of carbon between the biosphere and the atmosphere from biomass burning, Clim. Change, 2, 207-247, 1980.

Shea, R. W., Shea, B. W., Kauffman, J. B., Ward, D. E., Haskins, C. I., and Scholes, M. C.: Fuel biomass and combustion factors associated with fires in savanna ecosystems of South Africa and Zambia, J. Geophys. Res.-Atmos., 101, 23551-23568, 1996.

Siegert, F., Ruecker, G., Hinrichs, A., and Hoffmann, A. A.: Increased damage from fires in logged forests during droughts caused by El Niño, Nature, 414, 437-440, 2001.

Soares Neto, T. G., Carvalho Jr., J. A., Veras, C. A. G., Alvarado, E. C., Gielow, R., Lincoln, E. N., Christian, T. J., Yokelson, R. J., and Santos, J. C.: Biomass consumption and $\mathrm{CO}_{2}, \mathrm{CO}$ and main hydrocarbon gas emissions in an Amazonian forest clearing fire, Atmos. Environ., 43, 438-446, 2009.

Soja, A. J.: Estimating fire emissions and disparities in boreal Siberia (1998-2002), J. Geophys. Res., 109, D14S06, doi:10.1029/2004JD004570, 2004.

Sparks, J. C., Masters, R. E., Engle, D. M., and Bukenhofer, G. A.: Season of burn influences fire behavior and fuel consumption in restored shortleaf pine-grassland communities, Restorat. Ecol., 10, 714-722, 2002.

Stephens, S. L. and Finney, M. A.: Prescribed fire mortality of Sierra Nevada mixed conifer tree species: effects of crown damage and forest floor combustion, Forest Ecol. Manag., 162, 261271, 2002.

Stocks, B. J.: Fire behavior in immature jack pine, Can. J. For. Res., 17, 80-86, 1987a.

Stocks, B. J.: Fire potential in the spruce budworm-damaged forests of Ontario, Forest. Chron., 63, 8-14, 1987b.

Stocks, B. J.: Fire behavior in mature jack pine, Can. J. For. Res., 19, 783-790, 1989.

Stocks, B. J., Alexander, M. E., Wotton, B. M., Stefner, C. N., Flannigan, M. D., Taylor, S. W., Lavoie, N., Mason, J. A., Hartley, G. R., Maffey, M. E., Dalrymple, G. N., Blake, T. W., Cruz, M. G., and Lanoville, R. A.: Crown fire behaviour in a northern jack pine - black spruce forest, Can. J. For. Res., 34, 1548-1560, 2004.

Tomasella, J., Pinho, P. F., Borma, L. S., Marengo, J. A., Nobre, C. A., Bittencourt, O. R., Prado, M. C. R., Rodriguez, D. A. R., and Cuartas, L. A.: The Droughts of 1997 and 2005 in Amazonia: Floodplain Hydrology and Its Potential Ecological and Human Impacts, Clim. Change, 116, 723-746, 2013.

Smith, A. M. S., Tinkham, W. T., Roy, D. P., Boschetti, L., Kremens, R. L., Kumar, S. S., Sparks, A. M., and Falkowski, J.: Quantification of fuel moisture effects on biomass consumed derived from fire radiative energy retrievals, Geophys. Res. Lett., 40, 62986302, 2013.
Stockwell, C. E., Yokelson, R. J., Kreidenweis, S. M., Robinson, A. L., DeMott, P. J., Sullivan, R. C., Reardon, J., Ryan, K. C., Griffith, D. W. T., and Stevens, L.: Trace gas emissions from combustion of peat, crop residue, domestic biofuels, grasses, and other fuels: configuration and Fourier transform infrared (FTIR) component of the fourth Fire Lab at Missoula Experiment (FLAME4), Atmos. Chem. Phys., 14, 9727-9754, doi:10.5194/acp-149727-2014, 2014.

Stromgaard, P.: Biomass, growth, and burning of woodland in a shifting cultivation area of South Central Africa, Forest Ecol. Manag., 12, 163-178, 1985.

Tarnocai, C., Canadell, J. G., Mazhitova, G., Schuur, E. A. G., Kuhry, P., and Zimov, S.: Soil organic carbon stocks in the northern circumpolar permafrost region, Global Biogeochem. Cy., 23, GB2023, doi:10.1029/2008GB003327, 2009.

Toma, T., Ishida, A., and Matius, P.: Long-term monitoring of postfire aboveground biomass recovery in a lowland dipterocarp forest in East Kalimantan, Indonesia, Nutr. Cycl. Agroecosyst., 71, 63-72, 2005.

Turetsky, M. R. and Wieder, R. K.: A direct approach to quantifying organic matter lost as a result of peatland wildfire, Can. J. For. Res., 31, 363-366, 2001.

Turetsky, M.: Current disturbance and the diminishing peatland carbon sink, Geophys. Res. Lett, 29, 1526, doi:10.1029/2001GL014000, 2002.

Turetsky, M. R., Kane, E. S., Harden, J. W., Ottmar, R. D., Manies, K. L., Hoy, E., and Kasischke, E. S.: Recent acceleration of biomass burning and carbon losses in Alaskan forests and peatlands, Nat. Geosci., 4, 27-31, 2011.

Uhl, C. and Buschbacher, R.: A Disturbing Synergism Between Cattle Ranch Burning Practices and Selective Tree Harvesting in the Eastern Amazon, Biotropica, 17, 265, doi:10.2307/2388588, 1985.

United States Environmental Protection Agency (EPA): $2002 \mathrm{Na}$ tional Emissions Inventory Booklet. Research Triangle Park, North Carolina, available at: http://www.epa.gov/ttn/chief/net/ 2002neibooklet.pdf, last accessed: 20 November 2008.

Usup, A., Hashimoto, Y., Takahashi, H., and Hayasaka, H.: Combustion and thermal characteristics of peat fire in tropical peatland in Central Kalimantan, Indonesia, Tropics, 14, 1-19, 2004.

Vandergert, P. and Newell, J.: Illegal logging in the Russian Far East and Siberia, Int. Forest. Rev., 5, 303-306, 2003.

van der Werf, G. R., Randerson, J. T., Giglio, L., Collatz, G. J., Kasibhatla, P. S., and Arellano Jr., A. F.: Interannual variability in global biomass burning emissions from 1997-2004, Atmos. Chem. Phys., 6, 3423-3441, doi:10.5194/acp-6-3423-2006, 2006.

van der Werf, G. R., Randerson, J. T., Giglio, L., Collatz, G. J., Mu, M., Kasibhatla, P. S., Morton, D. C., DeFries, R. S., Jin, Y., and van Leeuwen, T. T.: Global fire emissions and the contribution of deforestation, savanna, forest, agricultural, and peat fires (19972009), Atmos. Chem. Phys., 10, 11707-11735, doi:10.5194/acp10-11707-2010, 2010.

Van Der Werf, G. R., Peters, W., Van Leeuwen, T. T., and Giglio, L.: What could have caused pre-industrial biomass burning emissions to exceed current rates?, Clim. Past., 9, 289-306, doi:10.5194/cp-9-289-2013, 2013.

Van Wagner, C. E.: The Line Intersect Method in Forest Fuel Sampling, For. Sci., 14, 20-26, 1968. 
Van Wilgen, B. W., Govender, N., Biggs, H. C., Ntsala, D., and Funda, X. N.: Response of Savanna Fire Regimes to Changing Fire-Management Policies in a Large African National Park, Conservat. Biol., 18, 1533-1540, 2004.

Vermote, E., Ellicott, E., Dubovik, O., Lapyonok, T., Chin, M., Giglio, L., and Roberts, G. J.: An approach to estimate global biomass burning emissions of organic and black carbon from MODIS fire radiative power, J. Geophys. Res.-Atmos., 114, D18205, doi:10.1029/2008JD011188, 2009.

Viereck, L. A., Van Cleve, K., and Dyrness, C. T.: Forest ecosystem distribution in the taiga environment, in: Forest Ecosystems in the Alaskan Taiga, edited by: Van Cleve, K., Chapin III, F. S., Flanagan, P. W., Viereck, L. A., and Dyrness, C. T., SpringerVerlag, New York, 57, 22-43, 1986.

Ward, D. E., Susott, R. A., Kauffman, J. B., Babbitt, R. E., Cummings, D. L., Dias, B., Holben, B. N., Kaufman, Y. J., Rasmussen, R. A., and Setzer, A. W.: Smoke and fire characteristics for cerrado and deforestation burns in Brazil- BASE-B Experiment, J. Geophys. Res., 97, 14601-14619, 1992.

Ward, D. E., Hao, W. M., Susott, R. A., Babbitt, R. E., Shea, R. W., Kauffman, J. B., and Justice, C. O.: Effect of fuel composition on combustion efficiency and emission factors for African savanna ecosystems, J. Geophys. Res.-Atmos., 101, 23569-23576, 1996.

Wiedinmyer, C., Akagi, S. K., Yokelson, R. J., Emmons, L. K., AlSaadi, J. A., Orlando, J. J., and Soja, A. J.: The Fire INventory from NCAR (FINN): a high resolution global model to estimate the emissions from open burning, Geosci. Model Dev., 4, 625641, doi:10.5194/gmd-4-625-2011, 2011.

Wooster, M. J., Zhukov, B., and Oertel, D.: Fire radiative energy for quantitative study of biomass burning: derivation from the BIRD experimental satellite and comparison to MODIS fire products, Remote Sens. Environ., 86, 83-107, 2003.

Wooster, M.: Boreal forest fires burn less intensely in Russia than in North America, Geophys. Res. Lett., 31, L20505, doi:10.1029/2004GL020805, 2004.
Wooster, M. J., Roberts, G., and Perry, G. L. W.: Retrieval of biomass combustion rates and totals from fire radiative power observations: FRP derivation and calibration relationships between biomass consumption and fire radiative energy release, J. Geophys. Res., 110, D24311, doi:10.1029/2005JD006318, 2005.

Yang, S., He, H., Lu, S., Chen, D., and Zhu, J.: Quantification of crop residue burning in the field and its influence on ambient air quality in Suqian, China, Atmos. Environ., 42, 1961-1969, 2008.

Yevich, R. and Logan, J. A.: An assessment of biofuel use and burning of agricultural waste in the developing world, Global Biogeochem. Cy., 4, 1095, doi:10.1029/2002GB001952, 2003.

Yokelson, R. J., Karl, T., Artaxo, P., Blake, D. R., Christian, T. J., Griffith, D. W. T., Guenther, A., and Hao, W. M.: The Tropical Forest and Fire Emissions Experiment: overview and airborne fire emission factor measurements, Atmos. Chem. Phys., 7, 5175-5196, doi:10.5194/acp-7-5175-2007, 2007a.

Yokelson, R. J., Urbanski, S. P., Atlas, E. L., Toohey, D. W., Alvarado, E. C., Crounse, J. D., Wennberg, P. O., Fisher, M. E., Wold, C. E., Campos, T. L., Adachi, K., Buseck, P. R., and Hao, W. M.: Emissions from forest fires near Mexico City, Atmos. Chem. Phys., 7, 5569-5584, doi:10.5194/acp-7-5569-2007, 2007b.

Yokelson, R. J., Burling, I. R., Gilman, J. B., Warneke, C., Stockwell, C. E., de Gouw, J., Akagi, S. K., Urbanski, S. P., Veres, P., Roberts, J. M., Kuster, W. C., Reardon, J., Griffith, D. W. T., Johnson, T. J., Hosseini, S., Miller, J. W., Cocker III, D. R., Jung, H., and Weise, D. R.: Coupling field and laboratory measurements to estimate the emission factors of identified and unidentified trace gases for prescribed fires, Atmos. Chem. Phys., 13, 89-116, doi:10.5194/acp-13-89-2013, 2013.

Zoltai, S. C., Morrissey, L. A., Livingston, G. P., and Groot, W. J.: Effects of fires on carbon cycling in North American boreal peatlands, Environ. Rev., 6, 13-24, 1998. 